VOL. 6

APRIL, 1932

No. 14

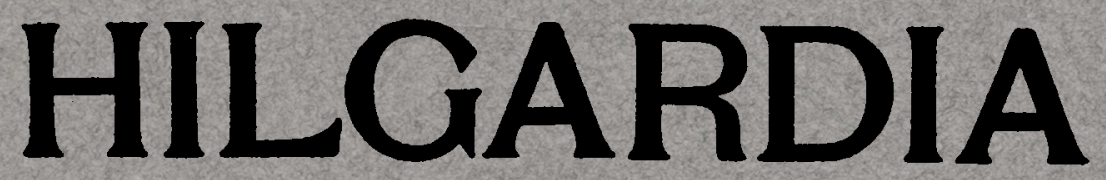

A Journal of Agricultural Science

PUBLISHED BY THE

California Agricultural Experiment Station

CONTENTS

The Structure and Development of Flowers in Ficus Carica L.

IRA J. CONDIT

UNIVERSITY OF CALIFORNIA PRINTING OFFICE

BERKELEY, CALIFORNIA 
The titles of the Technical Papers of the California Agricultural Experiment Station, which HIICARDIA replaces, and copies of which may be had on application to the Publications 8ecretary, Abricultural Experiment 8tation, Berkeley, are as follows:

4. Effect of Sodium Chlorid and Calcium Ohlorid upon Growth and Composition of Young Orange Trees, by II. 8. Reed and A. R. C. Haas. April, 1923.

5. Citrus Blast and Black Pit, by H. 8. Fawcett, W. T. Horne, and A. F. Camp. May, 1823.

6. A Study of Deciduous Fruit Tree Rootstocks with Special Beference to Their Identification, by Myor J. Feppner. June, 1923.

7. A Study of the Darkening of Apple Thasue, by E. I. Overholser and W. V. Oruess. June, 1923.

8. Effect of Salts on the Intakse of Inorganic Elements and on the Buffer System of the Plant, by D. R. Hoagland and J. C. Martin. July, 1923.

9. Experiments on the Reclamation of Alkali 8olls by Iseaching with Water and Gypsum, by P. L. Hibbard. August, 1823.

10. The Beasonal Variation of the Bojl Molsture in a Walnut Grove in Relation to the Hygroscopic Coefficient, by L. D. Batchelor and II. B. Roed. Sep. tember, 1928.

11. Studies on the Efrects of Sodinm, Potassium, and Calcium on Young Orange Trees, by II. B. Beed and A. 8. C. Haas. October, 1923.

12. The Effect of the Plant on the Beaction of the Culture solntion, by $\mathbf{D}$. $\mathbf{R}$. Hoagland. November, 1923.

14. The Respiration of Potato Tubers in Relation to the Occurrence of Blackheart, by J. P. Bennett and E. T. Bartholomew. Jannary, 1924.

16. The Molsture Equivalent as Influenced by the Amount of Soll Used in 1ts Determination, by F. J. Velhmeyer, 0 . W. Israelsen and J. P. Conrad. September, 1924.

17. Nutrient and Toxic Effects of Certain Ions on Oitrus and Walnut Trees with Especial Reference to the Concentration and $\mathrm{Ph}$ of the Modinm, by II. 8. Reed snd A. R. C. Hass. October, 1924.

18. Factors Influencing the Rate of Cermination of the Seed of Asparagus Ofilcinalls, by F. A. Borthwick. March, 1925.

19. The Rolation of the Subcutaneous Administration of Iiving Bacterium Abortum to the Immunity and Carrier Problem of Bovine Infectious Abortion, by Ceorge F. Hart and Jacob Traum. April, 1925.

20. A study of the Conductive Tissues in shoots of the Bartlett Pear and the Rolationship of Food Movement to Dominance of the Apical Buds, by Frank E. Cardner. April, 1926. 


\title{
HILGARDIA
}

\author{
A JOURNAL OF AGRICULTURAL SCIENCE \\ PUBLISHED BY THE
}

CALIFORNIA AGRICULTURAL EXPERIMENT STATION

VOL. 6

APRIL, 1932

No. 14

\section{THE STRUCTURE AND DEVELOPMENT OF FLOWERS IN FICUS CARICA L. ${ }^{1}$}

\author{
IRA J. CONDIT2
}

\section{INTRODUCTION}

The botanical and horticultural literature of the cultivated fig is voluminous and had its beginning in ancient times. Some ancient writers treated such subjects as caprification, varieties, and pests in greater or less detail. Recent European investigators have added materially to our knowledge of fig morphology and the peculiar relations existing between the fig, the caprifig, and the pollinating insect.

Perusal of the literature, however, reveals many discrepancies and gaps in our knowledge of the structure and development of fig flowers. Accounts of the development of the macrogametophyte are very incomplete and practically nothing is found concerning the development of the microgametophyte. It is the purpose, therefore, of this paper to cover as completely as possible the detailed floral morphology of Ficus carica, both by description and by illustration. This may help to prevent in the future such confused accounts as are now current in botanical and horticultural textbooks written by authors who are not personally familiar with the peculiar life history of the fig.

Before proceeding with the morphological details it may be well to review briefly some of the facts regarding the nature of the fig and the caprifig and the habits of the pollinating insect. Such facts are of common knowledge to growers of Smyrna figs and to practical horticulturists in fig districts but are somewhat shrouded in mystery or lacking in clarity to many others.

1 This paper was submitted to the Department of Botany and the Committee on Graduate Study of the Leland Stanford Junior University in partial fulfillment of the requirements for the Degree of Doctor of Philosophy.

2 Associate Professor of Subtropical Horticulture. 


\section{GENERAL MORPHOLOGY OF THE FIG}

The genus Ficus, to which the edible fig ( $F$. carica L.) belongs, is characterized by having its flowers borne inside a hollow receptacle or syconium. Horticulturally speaking, the fruit called the fig is the fleshy receptacle including the flowers; botanically speaking, the true fruits are the achenes within the syconium. To avoid confusion between horticultural and botanical terminology, the mature receptacle, the 'fruit' of the horticulturist, will be called the syconium in this paper.

In the syconia of all figs there is an apical ostiolum or eye which is usually more or less closed by scales. Within certain syconia of most if not all species of Ficus are various species of hymenopterous insects, the larvae of which develop from egg to adult inside the individual achenes. A fig flower the ovary of which contains the larva of a fig wasp is termed a gall flower. When the fig wasp emerges from the gall flower and leaves the syconium, it may be dusted with pollen if the staminate flowers near the ostiolum are mature at that time. Such pollen is carried to other figs which the insect enters to oviposit, and pollination is thus unwittingly accomplished.

Types of the Fig and Differentiation of Fruit Buds.-There are four general horticultural types of Ficus carica. The most primitive of these, the caprifig, has ovulate flowers with short-styled pistils (fig. $1 B$ ) and in many syconia staminate flowers also; the other three types (the Smyrna, White San Pedro, and the common), have ovulate flowers with long-styled pistils but have no staminate flowers.

Trees of the caprifig type charactistically produce three series of fruit buds each growing season. The first series of buds gives rise to the profichi or spring crop, the second series to the mammoni or summer crop, and the third series to the mamme or winter crop. The number of the series of fruit buds, however, depends upon climatic conditions. In the cool climate of Berkeley, California, and of southern France (Leclerc du Sablon, 1908a) the development of syconia is retarded, and only two series of buds mature, the mammoni crop being omitted. In the warmer climate of the Fresno district in California, the development is more rapid, and a second mammoni crop appears in late summer. In the extremely hot climate of Imperial Valley, California, there are seven more or less distinct generations of the blastophaga developing in as many crops of the caprifig tree (Condit, 1922). 
Trees of the three fig types bearing long-styled flowers (Smyrna, White San Pedro, and common) have the first series of buds maturing into a breba crop (in Italy called the fiori) corresponding to the profichi of the caprifig; the second series of buds develops into the main crop (pedagnuoli or forniti), corresponding to the mammoni of the caprifig. Fig trees of the common type occasionally produce a third series of buds (cimaruoli), the syconia of which may mature the same season, may be destroyed by frost, or may remain dormant during the winter and mature the following spring. The development of these syconia depends upon the horticultural variety, the temperature, and the length of the growing season. Trees of the Kadota and Brown Turkey varieties are especially prolific and syconia continue to develop until the cooler weather of fall induces dormancy.

The buds in the axils of leaves are not macroscopically evident until the internodes have ceased elongating (Condit, 1926). Some varieties have one or frequently two fruit buds and a vegetative bud axillary to nearly every leaf. Other varieties have the fruit buds more scattered and borne in the axils of occasional leaves only.

No perfect hermaphroditic flowers have as yet been reported in receptacles of Ficus carica $\mathrm{L}$. The flowers are fundamentally pistillate or staminate as the case may be, but rudimentary pistils are sometimes found in staminate flowers and rudimentary stamens in pistillate flowers.

The Caprifig Type and the Blastophaga.-The caprifig indigenous to southwestern Asia is the primitive type of cultivated fig, and the other three types of edible figs have undoubtedly evolved from it. The short-styled flowers of caprifigs are morphologically adapted to oviposition by the fig wasp (Blastophaga psenes L.), and syconia of each of the three crops of the caprifig tree harbor the larvae, pupae, and temporarily the adults of this insect. The presence of the immature blastophagas in mammoni and mamme figs is usually essential to their proper development on the tree. In some horticultural varieties of the caprifig, however, the profichi crop maturing in May or June consists of two kinds of syconia, those with and those without larvae in the gall flowers. Syconia inhabited by blastophagas normally keep green and plump until maturity and are designated as "insectiferous" figs (Eisen, 1896). On the same tree other syconia not inhabited by blastophagas develop parthenocarpically with an abundance of pollen and are known as "polleniferous" figs or "blanks." The latter are of no horticultural value, since the blastophagas are not present to distribute the pollen. 
The seasonal history of the blastophaga in the San Joaquin Valley of California is as follows: The larvae hibernate in syconia of the mamme crop during the winter, transform to pupae in March; the adult blastophagas emerge early in April and oviposit in syconia of the profichi crop. Eggs laid in the profichi develop into adult blastophagas that oviposit in syconia of the mammoni crop early in June. Eggs laid in the mammoni figs early in June have, by the end of July, developed into mature blastophagas which oviposit in syconia of the second mammoni crop. These second mammoni figs may mature during late summer or early fall or may persist on the trees and constitute the mamme crop from which adult blastophagas emerge the next spring.

The manner in which the blastophaga lays eggs and the subsequent development of the larvae have a distinct morphological significance in the life history of the fig (Solms-Laubach, 1882; Leclerc du Sablon, 1908b; Longo, 1909). During oviposition the blastophaga pushes its ovipositor through the stylar canal almost to its base and then directly through the lower part of the style into the ovule. Usually only one egg is deposited in each ovule. Leclerc du Sablon (1907) occasionally found two eggs or larvae in the same ovule, and one of my preparations shows three very young larvae developing side by side next to the nucellus.

The blastophaga egg is extruded between the inner integument and the nucellus (fig. $1 B$ ). This is invariably the position of the egg in my preparations, although in a few cases some nucellar cells are found to have been punctured by the tip of the ovipositor. Ravasini (1911) and Longo (1912b) report finding an egg occasionally within the nucellus, but Grandi (1929) never found one in such a location. Leclerc du Sablon (1908b) states that the egg is deposited more or less deeply in the nucellar tissue with a resultant enlargement of the nucellus due to a stimulation of cell division and an increase in cell size. My observations show a growth in size of the nucellus following oviposition, but this is due to an increase in size of cells by vacuolation rather than to an increase in their number. The swelling of the blastophaga egg after its extrusion from the ovipositor produces a pronounced concavity in the surface of the nucellus. The young larva first feeds upon the adjacent nucellar cells but later subsists upon the endosperm.

Oviposition and larval development are correlated with purplish or violet coloration of floral pedicels and perianth in syconia of some horticultural varieties of the caprifig, such as the Milco and Samson (Condit, 1922). In other varieties of the caprifig, such as the 
Stanford, and in all caprifigs of Ficus pseudocarica Miq. and $\boldsymbol{F}$. palmata Forsk, thus far observed, the pedicels and perianth lobes are white or greenish yellow in all stages of gall-flower development.

The caprifig is of no economic value except to perpetuate the blastophaga and to produce the pollen necessary to pollinate the flowers borne by figs of the Smyrna type. Pollination of the flowers of Smyrna figs with pollen carried to them by blastophagas from the profichi crop of caprifigs is called caprification. Man modifies the normal life history of the blastophaga by placing mature profichi of the caprifig in fig trees of the Smyrna type, thus causing pollendusted wasps to enter syconia of Smyrna figs instead of caprifigs. The female blastophagas, which generally lose their wings as they push their way between the scales of the ostiolum, crawl over the stigmas of the long-styled flowers in a vain attempt to oviposit. Thus, although there is no oviposition, there is pollination and a consequent fertilization and maturation of achenes in the Smyrna fig. Eventually the wasp emerges from or dies within the syconium.

Some syconia bearing short-styled pistillate flowers also bear separate and distinct staminate flowers. Such staminate flowers are abundant at the apical end of syconia of the profichi crop but are scarce or lacking in syconia of the mammoni and mamme crops. In some closely related species (Ficus pseudocarica. Miq., and $\boldsymbol{F}$. palmata Forsk.) the syconia of all three crops contain staminate flowers. The fig is protogynous, the anthers maturing from six to eight weeks after the stigmas of the pistillate flowers in the same syconium are receptive.

The Smyrna Type.-Syconia of the Smyrna type mature after the pollination of their long-styled flowers and a resultant development of the ovaries into achenes. Without such stimuli the immature figs of both the breba and main crops usually shrivel and drop when about an inch in diameter. Sometimes a few brebas develop parthenocarpically. The embryo and the endosperm of mature achenes account for the excellent quality of Smyrna figs. Horticultural varieties belonging to this type include Lob Injir (Calimyrna), Kassaba, and Bardajic. Smyrna-type figs are grown commercially in Turkey, Greece, Algeria, Portugal, California, and to a small extent in Spain.

The White San Pedro Type.-Figs of the White San Pedro type bearing long-styled flowers combine the characteristics of both the Smyrna and the common type on one tree. Brebas are of the common type and have a parthenocarpic development. Second-crop figs are of the Smyrna type, the syconia dropping unless the flowers are stimulated by pollination and the ensuing fertilization of the egg cell. Examples of varieties belonging to this type are the White 
San Pedro and the Gentile, neither of which is grown commercially to any extent.

The Common Type.-Figs of the common type have long-styled flowers which develop parthenocarpically and do not require the stimulus of pollination in order to have the syconia mature. Varieties of this type are the Mission of California, the Dottato of Italy (Kadota of California), and the Pajajero of Spain. The flowers of common-type figs were once regarded as incapable of producing fertile achenes and were therefore designated by Eisen (1896) as "mule flowers". Rixford (1918) and others, however, have proved that probably all common-type figs can produce fertile achenes if the flowers have been pollinated and fertilization has taken place.

Morphologically the flowers borne by figs of the Smyrna type and of the common type appear to be very similar. The difference between the two types lies in the fact that Smyrna fig receptacles, like the fruits of most angiosperms, require floral stimulation by pollination and the fertilization of the egg cell in order to develop to maturity.

\section{PHYLOGENY OF THE FIG}

Teratological specimens of figs described by Penzig (1894, p. 295) assist in explaining the structure of the syconium as a shortened, fleshy branch. This is especially noticeable when scales which normally line the ostiolum and sheathe the base or neck of the syconium appear on the surface in a regular, spiral sequence. Cook (1922) interprets these teratological forms as follows: "Since each of the scales may be supposed to represent the leaf of a specialized joint or internode of the fruit branch, the scales serve to indicate the number and arrangement of the internodes of which the fruit is composed. Interpreted in this way, the fleshy wall of the fruit evidently represents a series of internode elements standing side by side and completely fused though the scales remain distinct." 


\section{MATERIAL AND METHODS}

Syconia of the various series of fruit buds were collected during the 1929 and 1930 season at the Citrus Experiment Station, Riverside; at the University Farm, Davis; and from an orchard near Fresno. In certain series of collections regular fixations of material were made from the first appearance of the fruit until the syconia were mature. Other series of collections were of shorter duration and made to show certain stages of development.

The material collected and studied during the two years represented three species of Ficus ( $F$. carica L., $F$. pseudocarica Miq., and $F$. palmata Forsk.) growing in commercial orchards. Among these there were three horticultural varieties of the Smyrna type of fig, ten of the common type, ten of the caprifig type, three of the White San Pedro type, and two aberrant forms, the so-called Cordelia and the Hamma, which are edible caprifigs having both short-styled and staminate flowers in the same receptacle. Hamma figs require caprification in order to have the fruit set and mature but Cordelia figs develop by parthenocarpy.

A chrom-acetic-formalin killing and fixing solution of the following formula was used:

\section{Solution $A$}

65 ce water

10 ce acetic acid

1 gram chromic acid

\section{Solution $B$}

40 ce formalin (commercial) 35 ce water

One part of solution A is mixed with one part of B just before fixing. This solution proved more satisfactory than Bouin's, Carnoy's or Carnoy's plus Karpechenko's in a comparative test. It evidently penetrated the partly sclerified ovary wall with sufficient rapidity to fix mitotic figures in the endosperm, although Tischler (1912) found it desirable to remove the sclerified wall of the ovary before fixing.

Small pieces of the syconium with flowers attached were put through the usual processes of killing and fixing, dehydrating, and embedding in paraffine. Individual flowers of later stages were also used. Sections were usually cut 10 microns in thickness and stained in Haidenhain's iron-alum hematoxylin. In order to obtain preparations showing certain desired stages of development, it was necessary to mount, stain, and examine hundreds of slides, a large percentage of which were afterwards discarded. 


\section{STAMINATE FLOWERS AND THE DEVELOPMENT OF THE MICROGAMETOPHYTE}

Mature staminate flowers normally consist of a slender pedicel bearing a five-parted perianth and five very short filaments each supporting an introrse two-lobed anther.

The early development of the male flower within the syconium is very similar to that of many other angiosperms. When first recognizable the primordium is a small knob of embryonic tissue (fig. $1 C$ ), the apex of which generally develops into a rudimentary pistil having at its base the primordia of the anthers (fig. $1 D, E$ ).

Previous to this investigation rudimentary pistils were thought to develop in occasional staminate flowers only (Longo, 1919; Ravasini, 1911; Cotte and Reynier, 1923), but the present study has shown that rudimentary pistils are normal and not exceptional in staminate flowers. None of the ovules, however, developed to the macrospore mother-cell stage.

Anthers of caprifigs develop rather slowly. For a considerable period after oviposition by the female blastophaga in pistillate flowers in the same receptacle, they consist of a more or less homogeneous mass of parenchymatous cells enclosed by an epidermis. At an early stage the young anther is cordate in cross section and later develops two microsporanges in each lobe. The sporogenous cells are distinguishable by their denser cytoplasm. The tapetal layer surrounding the sporogenous tissue is one or two cells in thickness and distinguishable by the smaller size of its cells and their smaller nucleoli. The epidermis consists of a single layer of small cells each of which has a thick outer wall, a large vacuole, and a nucleus embedded in cytoplasm adhering to the inner wall.

Bordering the epidermis on the inside is the endothecium (fig. $1 F$ ), a prominent single layer of radially stretched cells with large vacuoles and lateral nuclei. On the thinner walls of the anthers the small epidermal cells are missing. The cells between the endothecium and the tapetum are parenchymatous and vacuolate with small nucleoli.

The sporogenous tissue consists of a mass of angular, large-nucleate cells extending almost the length of the anther, and is eight cells in diameter. The pollen mother cells, the last cell generation of this tissue, are at first angular; later they separate from one another, become rounded, and have somewhat thickened walls. During the 


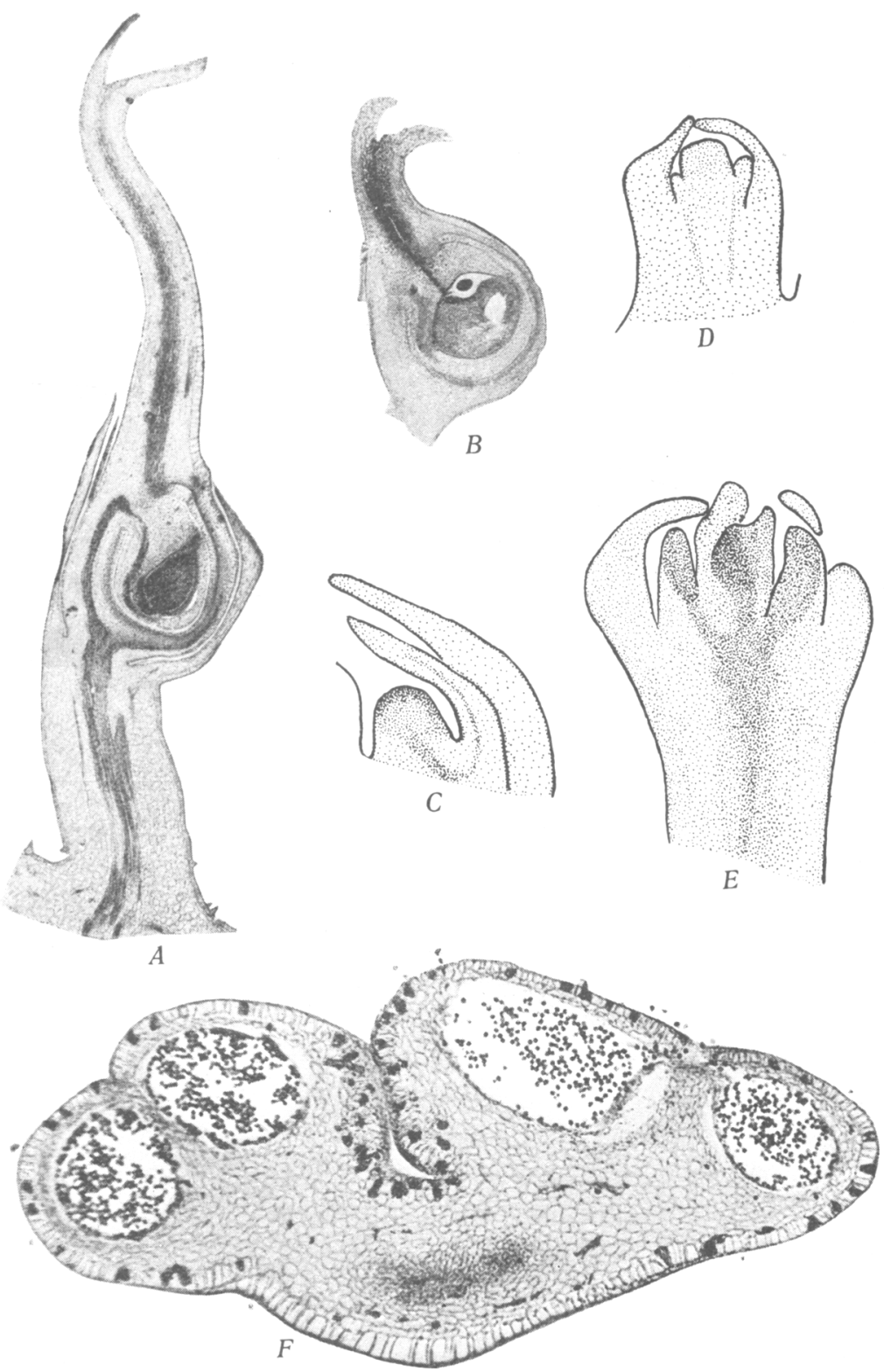

Fig. 1. A, A typical long-styled flower showing ovary, style, and two-lobed stigma. ( $X$ 28.)

$B$, A typical short-styled flower showing cells of stylar canal injured by ovipositor; the egg of blastophaga; the ovule and the embryo sac. ( $X$ 28.)

$C$, A staminate primordium with an over-arching ostiolar bract. (X 71.)

$D$, A staminate primordium with the anthers differentiating at its base. (X 71.)

$E$, A young staminate flower with anthers and rudimentary pistil. (X 71.)

F, Mature anther with four locules containing microspores, each locule bordered by an endothecium. ( $X$ 57.) 
development of the pollen mother cells the tapetal layers gradually disintegrate and the cytoplasm of the intervening layers of cells practically disappears.

The heterotypic and homotypic divisions in the pollen mother cells follow one another in rapid succession. Both divisions may be going on simultaneously in the same anther. At that time well-developed tetrads may be present in neighboring anthers. As a result of the first division of the mother cells the number of somatic chromosomes (twenty-six) is reduced to thirteen (fig. $8 \mathrm{~A}$ ) (Condit, 1928).

Microspores are usually tetrahedral in their arrangement in the tetrad stage, quadripartition taking place by furrowing. The production of microspores is profuse, several hundred being found scattered in each locule (fig. $1 E$ ). Very few defective microspores are found, practically all showing cytoplasm and a nucleus.

The mature pollen grains are spherical or broadly ellipsoidal, without surface markings, and about 11 microns in diameter. Pollen grains "beautifully and characteristically sculptured" (Eisen, 1896) have not been found during the present investigation. Ellipsoidal pollen grains commonly have a germ pore at each pole; spherical grains usually have three pores. The pollen grains germinate readily in a 5 per cent sugar solution.

Cotte and Reynier (1923) observed shriveling of pollen grains of syconia in which the gall flowers fail to develop. Such is not the case in California, where normal pollen is produced in profusion in 'polleniferous' or 'blank' caprifigs destitute of insect galls. Longo (1909) also reports the maturing of such figs containing normal pollen.

In order to have material available for the study of pollen-tube development at various stages, a large number of syconia of two horticultural varieties of Smyrna figs were pollinated by blowing pollen through the ostiolum into the interior of each syconium by means of a small pipette. Collections of these artificially pollinated figs were made at frequent intervals during the first few days and at greater intervals later.

Pollination of the stigmatic surface is evidently followed almost immediately by germination of the microspores. Short pollen tubes were distinguishable on stigmas collected $1 \frac{1}{2}$ hours after pollination. After 4 to 6 hours the pollen tubes had penetrated into the stigma to a depth of several cells, the course of a single tube being traceable with difficulty and for a short distance only. Microtome sections stained in Haidenhain's iron-alum hematoxylin or in magenta red failed to reveal the course of the pollen tube through the style and into the ovule. Borthwick (1931) found resorcin blue very satisfactory in dif- 
ferentiating pollen tubes and their callose plugs in preserved flowers of Daucus carota. L. This stain, however, did not give similar results when used on preserved fig flowers.

During the course of his investigation of parthenogenesis in Ficus hirta Vahl., Treub (1902) observed pollen grains germinating on the stigmatic surface but failed to find any evidence of pollen tubes either in the style or ovule, even in flowers where there was a development of the embryo. Longo (1909), who holds that the fig ovule lacks a micropyle, states that the slender pollen tube goes through the central collenchymatous tissue of the style, then through the apex of the internal integument to the apical region of the nucellus where the cells are especially rich in cytoplasm. He gives a diagrammatic illustration of the course of the pollen tube.

The growth of the pollen tube through the style and into the ovule is evidently fairly rapid. At Riverside, California, numerous syconia of Calimyrna fig trees were caprified on July 19. Flowers of syconia collected on July 23 showed a considerable development of endosperm and two days later several preparations of ovules showed two-celled embryos.

The stigmatic surface of short-styled caprifig flowers is just as favorable for the germination of pollen as that of long-styled flowers found in other types of fig. There is commonly a pollination of flowers of the mammoni and mamme crops, and fertile achenes are frequently found among the gall flowers in mature caprifig syconia. Leclere du Sablon (1908b) thinks that mammoni and mamme flowers normally have pollination and fertilization but that the development of the embryo is stopped by the growing larva. However, no investigator has ever discovered a gall flower containing both an immature embryo and a young blastophaga larva.

The reason for the absence of an embryo in flowers containing a blastophaga larva becomes evident when one examines the style of these flowers. The cells of the stigmatic surface are more or less injured as the insect seeks to insert its ovipositor into the funnelshaped apex of the style. There is also serious injury (fig. $1 B$ ) to the cells lining the stylar canal by the insertion and withdrawal of the ovipositor. Thus, even though pollen grains germinate, the growth of pollen tubes between the injured cells appears to be absolutely inhibited. The embryo of a plantlet and the larva of a blastophaga therefore could not be found in the same gall flower unless the embryo should develop parthenogenetically, or as the result of pollentube growth and fertilization of the egg before oviposition by the blastophaga. 


\section{PISTILLATE FLOWERS AND THE DEVELOPMENT OF THE MACROGAMETOPHYTE}

Mature pistillate flowers within a syconium typically have the following parts: a pedicel, five perianth lobes partly enclosing the spherical ovary, a simple style, and a stigma usually cleft into either equal or unequal limbs.

The primordia of pistillate flowers are at first indistinguishable from the primordia of staminate flowers. Normally in the primordia of both types of flowers the embryonic mass soon forms a symmetrical, encircling collar just below its apex. This collar becomes asymmetrical by its unequal development (fig. $2 B$ ). In pistillate primordia one side of the collar elongates more rapidly than the other, and eventually develops into the long limb of the stigma (figs. $2 C, D$ ). The other side of the collar, which grows more slowly, develops into the short stigmatic limb. A central pore or stylar canal (fig. $2 D$ ) more distinct in some styles than in others, is left as the collar elongates. No long-styled flowers with staminate primordia have been found during this investigation, although Leclerc du Sablon (1908a) reports the occurrence of such hermaphroditic flowers in rudimentary stages.

The primordia of both staminate and pistillate flowers are borne on pedicels of various lengths, the surface of which may be smooth or armed with scattered spicules. One-celled spicules similar to those on the outer epidermis of the syconium are thickly scattered on the inner surface of the receptacle between the pedicels.

Perianth.-The primordia of the perianth lobes (fig. $2 A$ ) appear in acropetalous succession at the base of the central pistillate primordium before the formation of the apical collar. The fig flower, typically pentamerous, may have only three or four perianth lobes or occasionally six or seven. According to Eisen (1896) the "petals" of both staminate and pistillate flowers are generally four in number but those of staminate flowers are shorter than those of pistillate flowers. Leclerc du Sablon (1908a) calls the perianth lobes "sepales" and states that their number, though generally four or five, is of no more importance than the number of stamens, usually four or five. In this investigation actual counts of the perianth lobes of 71 flowers from six horticultural varieties of figs and caprifigs showed 31 flowers with five lobes, 19 with four, 16 with six, 4 with three, and 1 with seven lobes. 
The perianth lobes are mostly broadly lanceolate and united to one another at the base. Occasionally two lobes are joined together for half their length or more. The margins of the perianth lobes are mostly entire, though sometimes serrate near the apex, and are generally armed with prominent apical spines or spicules. The lobes

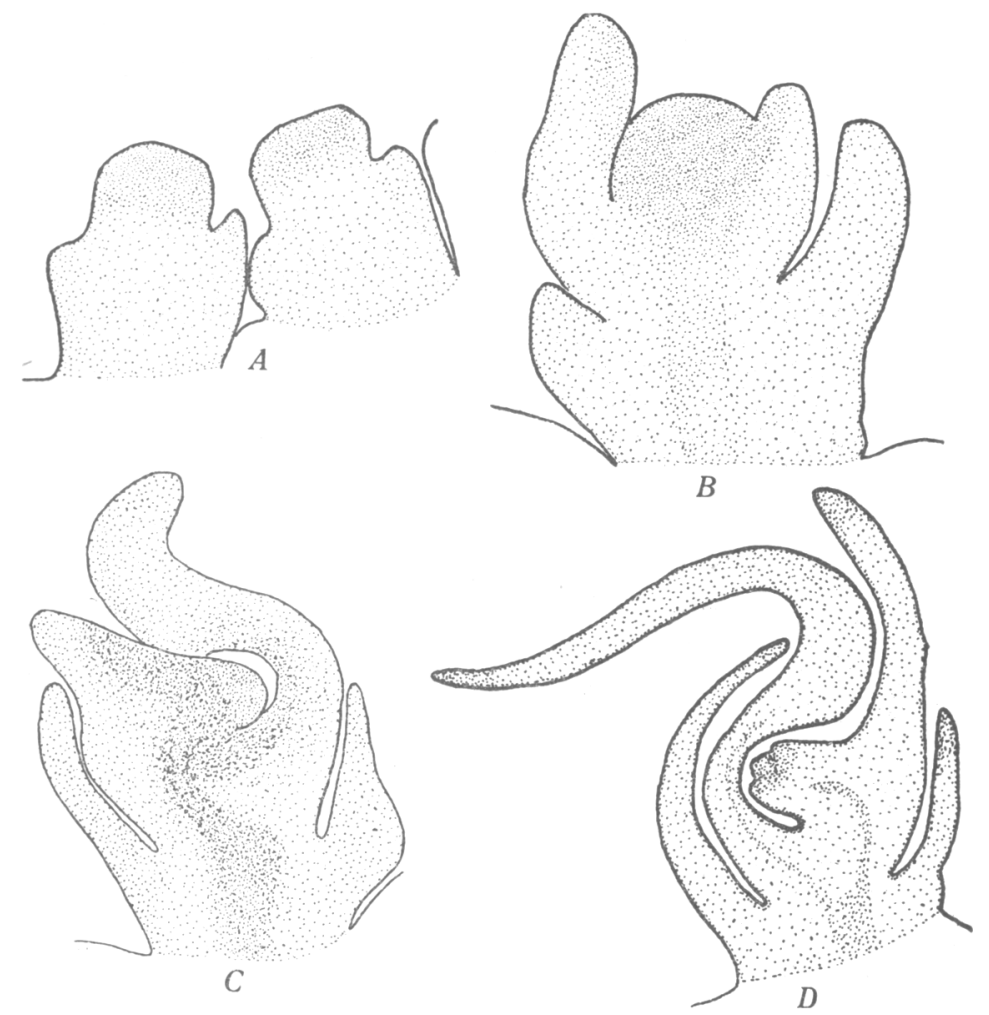

Fig. 2. $A$, Perianth lobes differentiating laterally from primordia of pistillate flowers. (X 184.)

$B$, Primordium of pistillate flower differentiating at its apex into an asymmetrical circular collar. ( $X$ 184.)

$C$, Further differentiation of apex of primordium into style and stigma. (X 133.)

$D$, Long-styled flower after differentiation from the primordium of ovary, style, stylar canal, unequal stigmatic lobes, and perianth. (X 75.)

may be equal in length to the style in short-styled flowers but are always much shorter than the style of long-styled flowers.

Style.-The stylar primordia, formed in the manner already described, develop into short, stubby styles (fig. $1 B$ ) characteristic of flowers borne in syconia of the caprifig type or into long, slender 
styles (fig. $1 A$ ) found in flowers of the Smyrna, White San Pedro, and common types of figs. In general, the length of style in shortstyled flowers is from 0.55 to $0.70 \mathrm{~mm}$ and in long-styled flowers from 1.5 to $2.0 \mathrm{~mm}$. The thickness, form (straight, curved, or bent at an angle), and length of style in long-styled flowers vary considerably according to the horticultural variety of fig studied. These and other characters are of taxonomic value in the study of fig varieties. Leclerc du Sablon (1908a) found a continuous series of flowers ranging in length from those with short styles to those with very long styles.

The surface of the style of fig flowers may be smooth or studded more or less thickly with sharp, slender spicules. Within some of the cells of the style there are commonly found single, large crystals of calcium oxalate, as mentioned by Ravasini (1911).

Various writers refer to the style of caprifig flowers as being hollow, especially toward the apex, although both Longo (1909) and Ravasini (1911) describe it as funnel-shaped, a better descriptive term. The funnel-shaped apex of the style assists the blastophaga in introducing her ovipositor into the stylar canal.

Stigma.-As already stated, bifid stigmas (fig. 1A) are characteristic of most fig flowers. This character, however, is somewhat variable, both simple and bifid stigmas being found in flowers of the same receptacle. Flowers of the Mission fig may have simple stigmas or there may be found a second very short stigmatic lobe at the base of the longer one. In most bifid stigmas one lobe is much longer than the other. The stigmatic lobes of many varieties of common and of Smyrna-type figs are very prominent, almost equal in length, and spread out horizontally. The lobes of the stigma of the Hamma fig are unusually long, much longer in fact than those of any other fig flower examined. Actual measurements of the stigmatic lobes of various fig flowers show the following:

\begin{tabular}{|c|c|c|c|}
\hline Variety & $\begin{array}{c}\text { Length of } \\
\text { longer limb } \\
m m\end{array}$ & $\begin{array}{c}\text { Length of } \\
\text { shorter limb } \\
\mathrm{mm}\end{array}$ & $\begin{array}{c}\text { Length of } \\
\text { simple stigma } \\
\mathrm{mm}\end{array}$ \\
\hline Calimyrna & 0.77 to 1.08 & 0.40 to 0.66 & \\
\hline Mission & .88 & .16 to .33 & 1.00 to 1.10 \\
\hline White San Pedro .................. & .88 to .99 & .35 to .75 & ........................ \\
\hline Hamma & .99 to 1.26 & .66 to .93 & ....................... \\
\hline Roeding No. 3 caprifig...... & 0.40 to 0.70 & 0.10 to 0.40 & 0.50 to 0.55 \\
\hline
\end{tabular}

Flowers of brebas and second-crop figs of the same variety are similar in stigmatic characters.

The line of demarcation between the surface of the style and stigma is often difficult to determine when entire flowers are examined. 
In longitudinal sections, however, the demarcation is usually apparent. The epidermal cells in the region of the stigma are rectangular with thick outer walls. The stigmatic surface consists of elongated, diagonally arranged cells with thin walls. These papillate cells are found on the stigmas of both long and short-styled flowers.

The stigmas remain receptive to pollen two weeks or more at ordinary temperatures.

Ovary.-The ovary is formed from the basal part of the immature pistil. As seen in longitudinal section the ovary is asymmetrical, the wall on the side of the funiculus and the short limb of the stigma being much thicker than the other. The stylar canal leads to the locule of the ovary which is almost completely filled by the ovule.

The ovary wall consists of more or less distinct layers (four according to Ravasini, 1911) of cells (fig. 3). At the outside is an epidermal layer continuous with and similar to that of the style. The cells of the innermost layer are continuous with but larger and more regular in shape than those lining the stylar canal. During the period of development of the macrogametophyte their general appearance is similar to that of the epidermal cells. Between these two layers are three or four other tiers of cells showing at first no special differentiation. At the macrospore mother-cell stage the spiral vessels of the vascular tissue are distinguishable in the intermediate cell layers of both the thick and thin portions of the ovary wall. Adjacent to the innermost layer there becomes differentiated a single or sometimes double layer of small cubical or palisade-like cells (fig. 3) rich in cytoplasm. Further differentiation of the cells composing the various layers takes place after maturity of the macrogametophyte.

Oviposition by the blastophaga in the short-styled flowers and the development of the young larva result in a gradual thickening of outer walls in the epidermal layer. There is also a gradual sclerification of the two inner layers of cells forming the ovary wall. Sclerotic cells are well developed and section with some difficulty even while the larva is still fairly young. Material showing eggs of the blastophaga on April 3 showed young larvae and well-sclerified ovary walls on April 21. The greatest amount of sclerification takes place in the cells of the innermost layer, the adjacent small square cells becoming sclerified but remaining about the same size. The epidermal and intermediate cell layers remain attached as a dry outer covering to the sclerified ovary wall of the mature gall flower. According to Leclerc du Sablon (1908b) there is in the same syconium less sclerification in the ovary wall of flowers which harbor a blastophaga larva than in the wall of the few flowers which contain a plant embryo. 


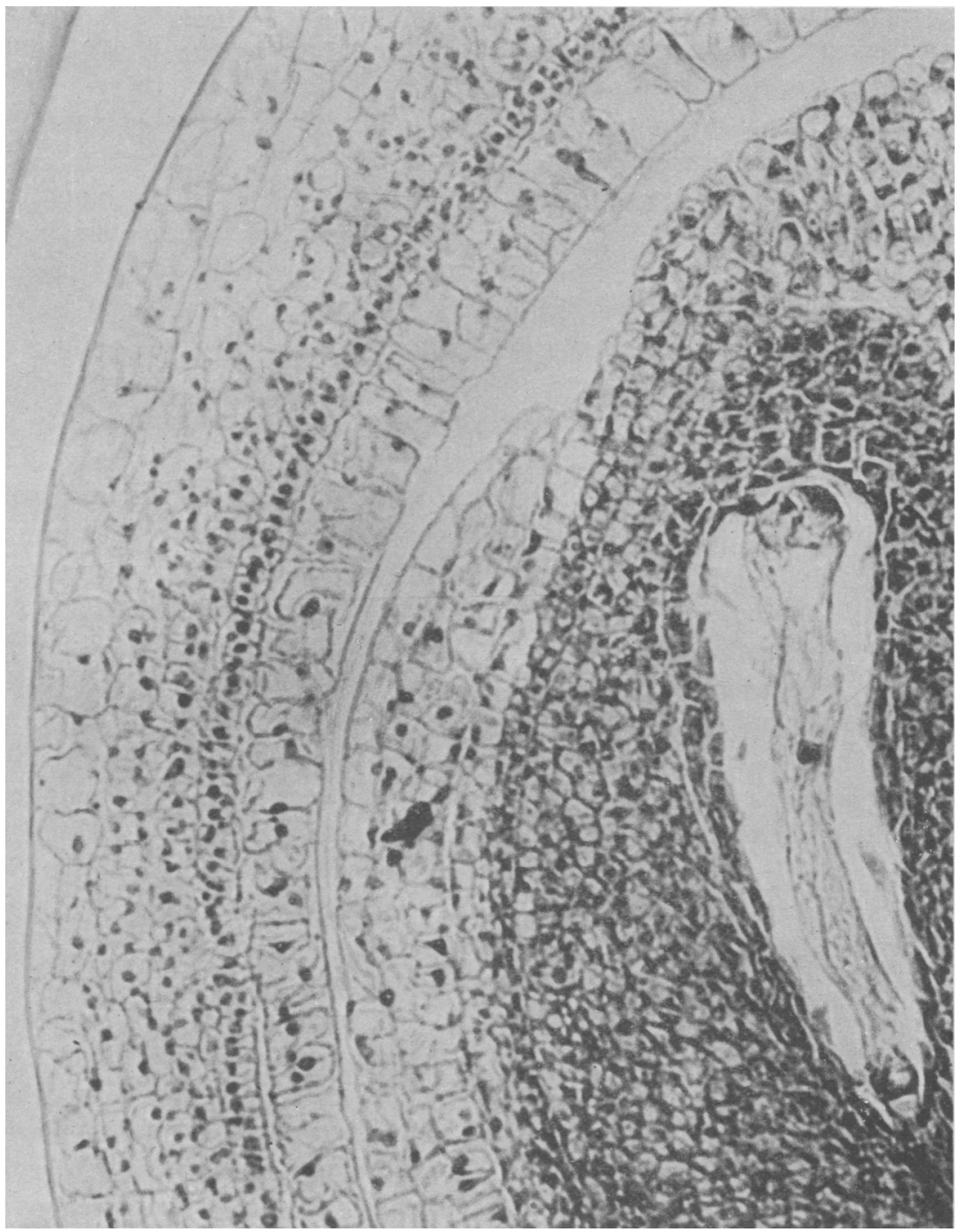

Fig. 3.-The ovary at the time of maturity of the macrogametophyte, showing the cell layers of the ovary wall, the outer and inner integuments, and the nucellus enclosing the embryo sac. ( $X$ 450.) 
There is, however, but little sclerification at the junction of the funiculus and the base of the style. The adult blastophagas escape through this partly sclerified region in the ovary wall. Short-styled flowers in which there is neither a blastophaga nor an embryo do not, with the exception of such figs as the Cordelia, have any development or sclerification of the ovary wall. The achenes of long-styled flowers, which never contain a blastophaga, usually have a well-sclerified ovary wall.

Cell layers in the young ovary wall of long-styled flowers are very similar to those of the short-styled flowers. Sclerification (fig. 4) takes place in the same way and to about the same extent in the innermost cell layer and in the adjacent small cells. The epidermal cells become considerably enlarged and radially stretched and their outer walls thicken materially (fig. 7). The pulpy part of edible figs consists of the thicker layers of unsclerified cells in the ovary wall. These cells, as well as those of the pedicel and style, remain parenchymatous and serve as storage tissue. Some caprifigs have a certain amount of such parenchymatous tissue which becomes pulpy. In the Cordelia fig the surface cells of the ovary wall are developed to the same extent as in most edible figs with long-styled flowers. Adult blastophagas if present in the mature Cordelia figs usually perish in the mass of pulpy flowers. Pulpy, edible caprifigs are also common in the mammoni crop of such varieties as the Milco.

Such horticultural varieties of the fig as Mission, Brown Turkey; and White Marseilles have numerous hollow and infertile achenes with the ovary wall fully sclerified. Other varieties with infertile achenes, such as the Dottato (Kadota) and Brunswick (Magnolia), do not have the ovary wall as fully sclerified nor as well developed as in the plump achenes of most common figs. To call such figs seedless is incorrect; Traub and Fraps (1928) record an average of 406 infertile achenes in Magnolia figs.

The term phenospermy is used (Goodspeed, 1915) to describe the production of seeds which appear to be normal but consist of empty seedeoats only. The term cenocarpy is hereby proposed to describe the production of a fruit or an achene which has a normally developed ovary wall but does not contain an embryo.

The stone cells of the sclerenchyma in the ovary wall of fig flowers are sufficiently characteristic of the species to enable their identification in food preparations such as marmalade, jam, and coffee substitutes. According to Winton (1916, pp. 386-390), who reproduces the account and illustrations of Moeller (1886, pp. 287-290), the outer sclerenchyma consists of a single layer of small stone cells 15 


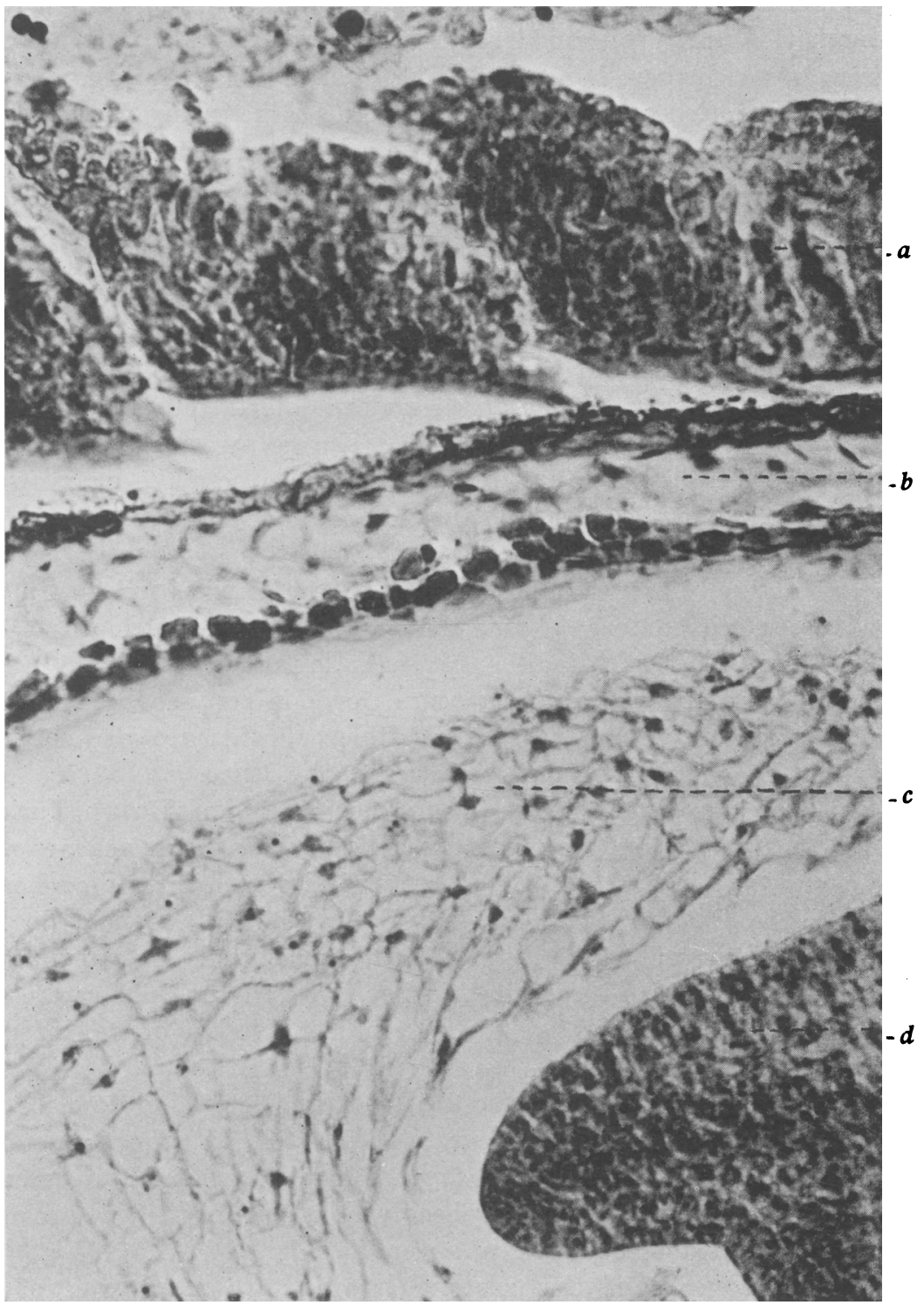

Fig. 4.- Immature achene showing $a$, the sclerified ovary wall; $b$, the seed coat formed by the integuments; $c$, the endosperm cells, cambium-like in appearance; and $d$, portion of the young embryo. (X 450.) 
microns in diameter. The endocarp or inner sclerencyma is composed of one or more layers of rounded, angular stone cells about 50 microns in diameter. Each cell has a narrow lumen and thick walls with distinct, concentric layers perforated by branching pores.

Ovule.-There is usually a single ovule within the ovary. Bi- or triovulate ovaries with more or less deformed ovules are more frequent in some horticultural varieties, such as the White San Pedro, than in others. Longo (1909) states that in first-crop figs multiovulate ovaries are more common than uniovulate ones.

Specimens of the Black Douro variety of fig collected at Fresne, April 16, showed two distinct types of flowers with respect to the ovary, one with a normal and the other with a double ovary. Such flowers were also found, but less commonly, in the Dauphine, Datte, and Black Ischia varieties of fig. Flowers with a double ovary are symmetrical, with equal bulging sides and similar stigmatic lobes. Sections show a central vascular strand in the pedicel branching off on either side to the funiculus of each ovule. However, no mature achenes with a double ovary have been found. Similar biovulate ovaries have been recorded by Solms-Laubach (1882) and by one or two other writers.

The ovule and the stigmatic lobes differentiate about the same time. The very young ovule is a hemispherical meristematic mass (the nucellus), from the base of which there successively develop the inner and then the outer integuments, the inner growing more rapidly. At the time of differentiation of the macrospore mother cell, the apex of the nucellus is in some flowers almost completely enclosed by the inner integument. In other flowers the nucellus is only half covered by the inner integument at this stage. At the time of maturity of the macrogametophyte, a cap-like mass of cells of the inner integument covers the micropylar end of the nucellus (figs. 3, 5) about as deeply as the underlying nucellar cells cover the cavity of the sac itself. Longo (1909) states that in multiovulate ovaries the nucellus is not always covered by the internal integument but protrudes from it like a large, more or less pointed nipple. The outer integument (fig. 3) never develops sufficiently to cover the apical portion of the inner integument.

Leclere du Sablon (1908 $b$ ) states that each integument is five cells in thickness, the cells of the outer integument generally persisting during development of the ovule, those of the inner one being digested by the underlying tissue. My preparations show the inner integument to be three or more cells in thickness (fig. 3), the internal layer consisting of rectangular cells much smaller than the nucellar cells 


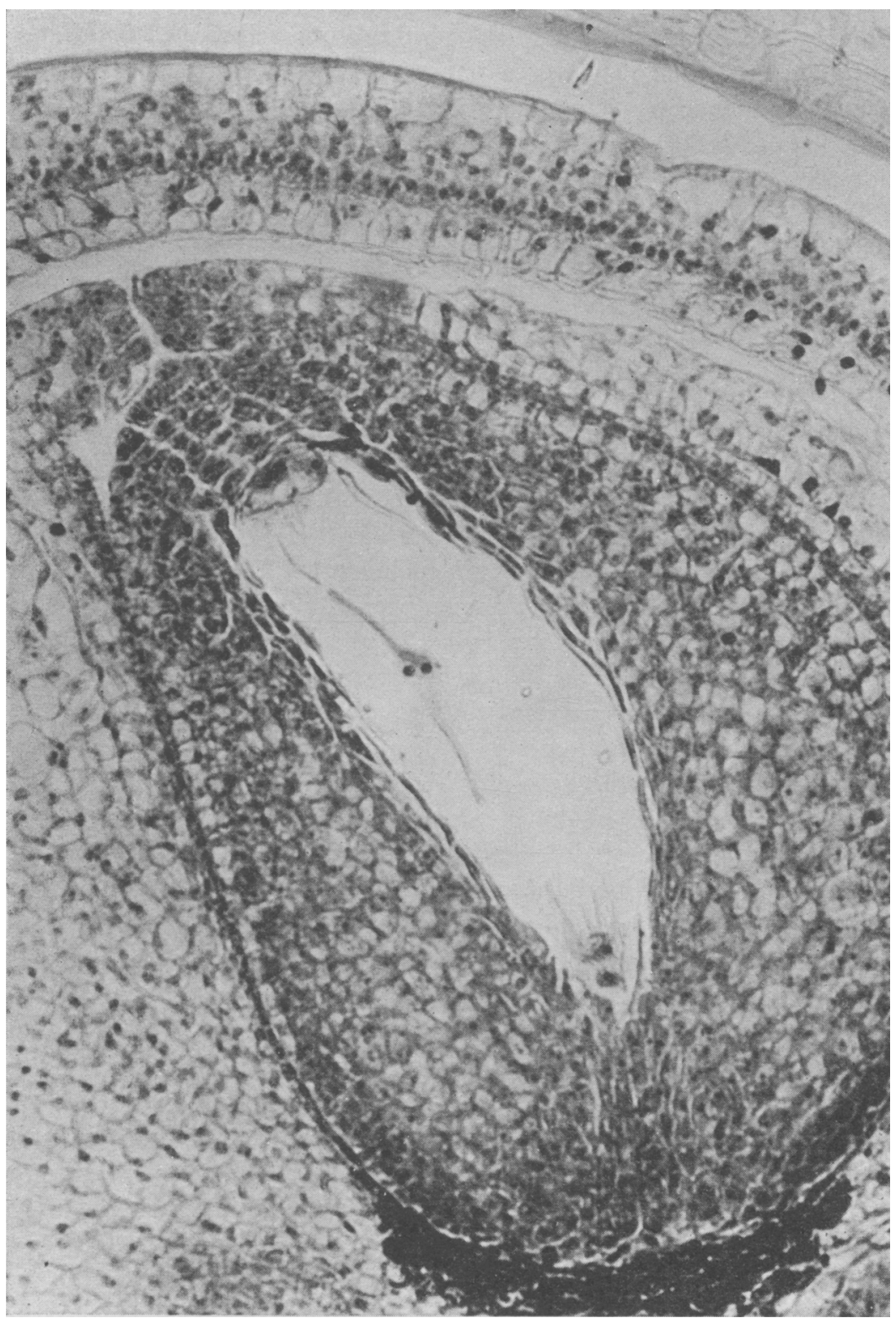

Fig. 5.-Mature macrogametophyte with synergids, egg cell, two polar nuclei, and two of the three antipodals. A micropyle is plainly in evidence at the apex of the inner integument. ( $X$ 450.) 
adjoining. The external layer is composed of large, more or less oblong cells with the nucleus and cytoplasm next to the outside wall. The outer integument is also from three to five cells in thickness (fig. 3), the individual cells being still larger than the adjoining cells of the inner integument.

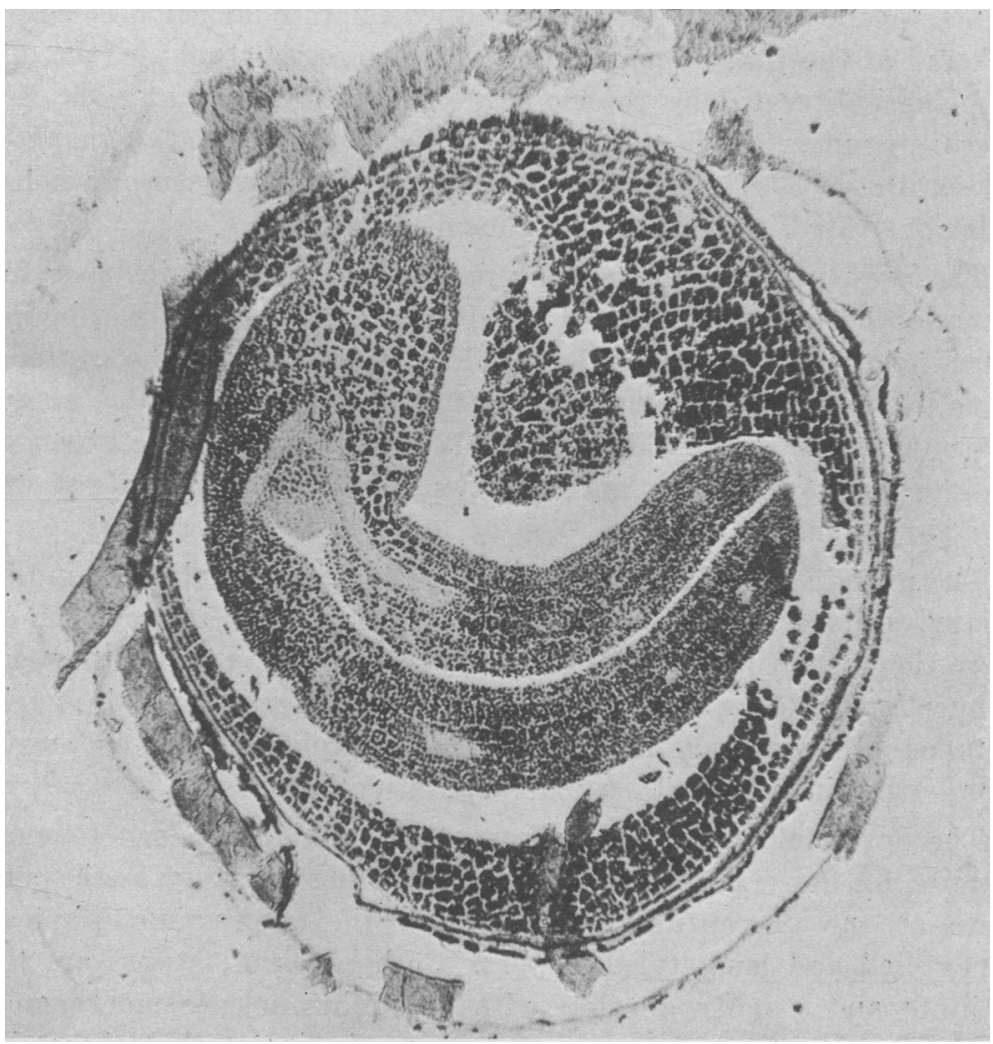

Fig. 6.-Mature achene with embryo surrounded by endosperm, seed coat, and pieces of sclerified ovary wall. ( $X$ 68.)

In long-styled flowers the internal layer of the inner integument and the external layer of the outer integument become filled with a deeply stainable substance (figs. 4,7) during the early stages of embryonal development and also during the development of cenocarpic achenes. These prominently staining layers persist unchanged in the seed coat developing from the integuments (fig. 6) but the other integumentary cells lose their contents and become more or less crushed during the later stages of achene development. 
Short-styled flowers containing the larva of a blastophaga do not have this differentiation of the integumentary layers, their cells being finally consumed by the developing larva. Achenes of short-styled flowers in which there is development of an embryo, do show a differentiation of the integuments into a seed coat.

A micropyle is distinctly in evidence at the two-nucleate stage of the macrogametophyte. A clearly defined micropylar canal can rarely be found at the time of maturity of the macrogametophyte, the opening being obliterated by the closing together of adjacent cells of the inner integument. There must, however, be a line of demarcation between the cells. The presence of a micropylar canal can occasionally be demonstrated, as in the ovule shown in figure 5 .

The presence or absence of a micropyle was the main basis for a discussion between Ravasini (1911, 1912a, 1912b), who described and figured one, and Longo (1911a, 1911b, 1912a, 1912b) who contended it was lacking at the two-nucleate (or at most four-nucleate) stage of the young embryo sac. Tischler (1912) also reported the absence of a micropylar opening at the completion of the eight-nucleate stage of the embryo sac.

The nucellus itself is composed of an immense number of undifferentiated cells irregularly arranged except at the micropylar end, where they are in more or less vertical rows. Some ovaries show cases of nucellar budding or continued meristematic activity in various parts of the nucellus, resulting in odd proliferations or even in secondary primordia with a macrospore mother cell.

The development of the macrosporange and of the macrogametophyte of fig flowers is similar to that occuring in many angiosperms. There are no perceptible differences in the macrogametophytes of short-styled and long-styled flowers. Both kinds of flowers are truly pistillate and usually develop with an eight-nucleate macrogametophyte. Furthermore, the present evidence indicates that the embryo sacs in first and second-crop figs and in the flowers of all crops of the caprifig tree are similar, all embryo sacs containing an egg cell and a polar nucleus being potentially capable of fertilization.

In the development of the ovule the macrospore mother cell becomes deeply embedded within the nucellus, because of an extensive development of the parietal tissue, the cells of which are regularly arranged. The reduction division was observed in a few cases but chromosome counts were not obtained. Some preparations showed the linear tetrad or the four-macrospore stage but none were found showing clearly the nonfunctional spores or their degeneration. The tetrads are 
not always in a linear arrangement, the four macrospores sometimes being found in two adjacent groups near the center of the sac.

After the division of the nucleus in the functional macrospore the daughter nuclei migrate, one to each end of the embryo sac. The four-nucleate and the eight-nucleate stages soon follow, the latter being attained while the embryo sac is still much smaller in size than it is at maturity. In the mature macrogametophyte, the egg and two synergids are at the micropylar end, the two polar nuclei at the center and the three antipodals at the chalazal end (fig. 5). The egg is indistinguishable in size and appearance from the synergids. The fusion of the polar nuclei takes place well before the time of fertilization.

An ovule with a complete embryo sac is shown diagrammatically by Ravasini (1911). Leclerc du Sablon's (1908b) preparations showed mature embryo sacs but not the egg apparatus or the antipodals. The synergids were found by Tischler (1912) to be similar to the egg cell, differing only in their much smaller protoplasmic content. He illustrated the egg and synergids but not the antipodals, which were poorly differentiated in his material.

\section{THE ENDOSPERM}

The Development of Normal Endosperm.-There is no reason for believing that development of endosperm in the fig flower is other than normal, even though the actual fusion of a sperm nucleus with the polar nuclei has not been observed. This is indicated by the fact that mitoses of endosperm nuclei show approximately the $3 \mathrm{n}$ complement of chromosomes (fig. $8 \mathrm{~B}$ ). There is a considerable multiplication of endosperm nuclei before the division of the zygote. A continuous series of thirteen sections of one ovule, with the embryo at the twocelled stage, showed 273 free endosperm nuclei well distributed about the periphery of the embryo sac. Chromosome counts are not at all difficult in somatic mitoses of properly prepared root-tip material of the fig; polar views of metaphase plates show the chromosome complement well distributed and mostly in one plane (Condit, 1928). But chromosome counts of metaphase plates of endosperm nuclei are made with difficulty, not so much on account of the extremely small size of individual chromosomes as on account of their close grouping in a dense mass of cytoplasm. Counts of a few metaphase plates (fig. $8 \mathrm{~B}$ ) showed from 33 to 37 of the 39 chromosomes which should be present. 
The nuclei of the young endosperm are spherical or ellipsoidal in shape and 6.5 to 10.0 microns in diameter. Both the nuclei and nucleoli are at least twice the size of those in the adjacent nucellar and integumentary tissue. A single nucleus may have one large nucleolus or as many as five nucleoli equal or unequal in size. The peripheral zone of free-nucleate endosperm becomes cellular by cleavage when the spherical embryo consists of three or four hundred cells, the delicate plasma membranes appearing first in the region of the embryo.

The newly formed cells are at first polygonal but later those toward the periphery enlarge radially and have a more or less regular arrangement of their plasma membranes. The further development of this tissue must be interpreted from the arrangement of cells since divisions in cellular endosperm were not found in my material. The central cavity of the embryo sac becomes completely filled with uninucleate protoplasts, and these irregular protoplasts at the center eventually become separated from one another by cellulose walls. The cells at the periphery apparently divide periclinally, forming a layer of small cells regularly arranged and cambium-like in appearance (fig. 4). This process of cell formation by cleavage in the normal endosperm is quite different from the furrowing process described later in the parthenogenetic development of endosperm in short-styled flowers.

Nuclear fusions may sometimes occur during the early cellular stages in development of the normal endosperm, but to a very much smaller extent than in a parthenogenetic endosperm. As Leclerc du Sablon $(1908 b)$ has shown, albuminoid granules appear in the cellular endosperm after the cotyledons of the embryo have become well differentiated. He holds that many of these granules are of the nature of aleurone grains. In the mature achene (fig. 6) the endosperm cells are densely packed with spherical granules of different sizes. According to Winton $(1916$, p. 389$)$ the mature endosperm makes up about half of the bulk of the achene and consists of thick-walled, polygonal cells containing proteid matter and fat.

The Parthenogenetic Development of Endosperm.-The flowers of any type of fig which have had a normal development of the macrogametophyte and into which no sperm nuclei have entered, may have a development of endosperm. Such endosperms are called parthenogenetic but their development is not the same in long and in short-styled fig flowers.

The most careful cytological study of this parthenogenetic develop- ment of endosperm has been made by Tischler (1912) with material 
from the syconia of a common-type fig containing long-styled flowers. He finds that the first cells formed in the endosperm are often multinucleate but that later many become uninucleate by a fusion of their nuclei. The process of cell formation is not described, although he states it proceeds independently at opposite poles of the embryo sac.

Tischler describes the endosperm nuclei as being very irregular in size owing to their fusion, a phenomenon seen in all stages, especially in the multinucleate cells. The differences in size of nuclei and cells are found to be more striking in the mature endosperm than in the early stages. Tischler failed to find mitoses of endosperm nuclei but does not conclude, as does Longo (1909), that division is by fragmentation. He states that the cells of the mature parthenogenetic endosperm contain considerable reserve material similar to that of the normal endosperm. Later he found a disintegration or digestion of the mature cells, taking place from the center towards the periphery, through the action of enzymes secreted by the endosperm cells themselves.

Tischler states that the egg cell usually persists, and in some cases increases to an immense size, greater than that reported for the egg cell of any other angiosperm. One of his preparations showed that there had been repeated mitoses of the egg nucleus but this was not followed by cytokinesis. This egg cell contained approximately 132 free nuclei.

During the present investigation, a certain amount of parthenogenetic development of endosperm was found in long-styled flowers collected from brebas of five varieties of the common type, two varieties of the White San Pedro type, and one of the Smyrna type of fig. Since collections of material were not made for the express purpose of studying this parthenogenetic endosperm, a continuous series of developmental stages was not obtained. The first division of the nucleus resulting from the fusion of the two polar nuclei and subsequent divisions of the daughter nuclei proceed tardily. The rate of development is also irregular from flower to flower. Material collected on April 3 showed long-styled flowers with stigmas receptive to pollen and with fully developed embryo sacs. Material colleeted on April 29 from the same trees showed in many ovaries a single, prominent, polar fusion nucleus and a degenerated egg apparatus; but some ovaries showed a very scanty and others a profuse development of the endosperm (fig. 7). In a few cases the daughter nuclei were found to be densely clustered in small masses rather than widely distributed in a peripheral layer. Mitotic figures, though scarce, were normal. Counts of a few metaphase plates showed 24 or 25 chromosomes, indicating the $2 \mathrm{n}$ complement of chromosomes. 


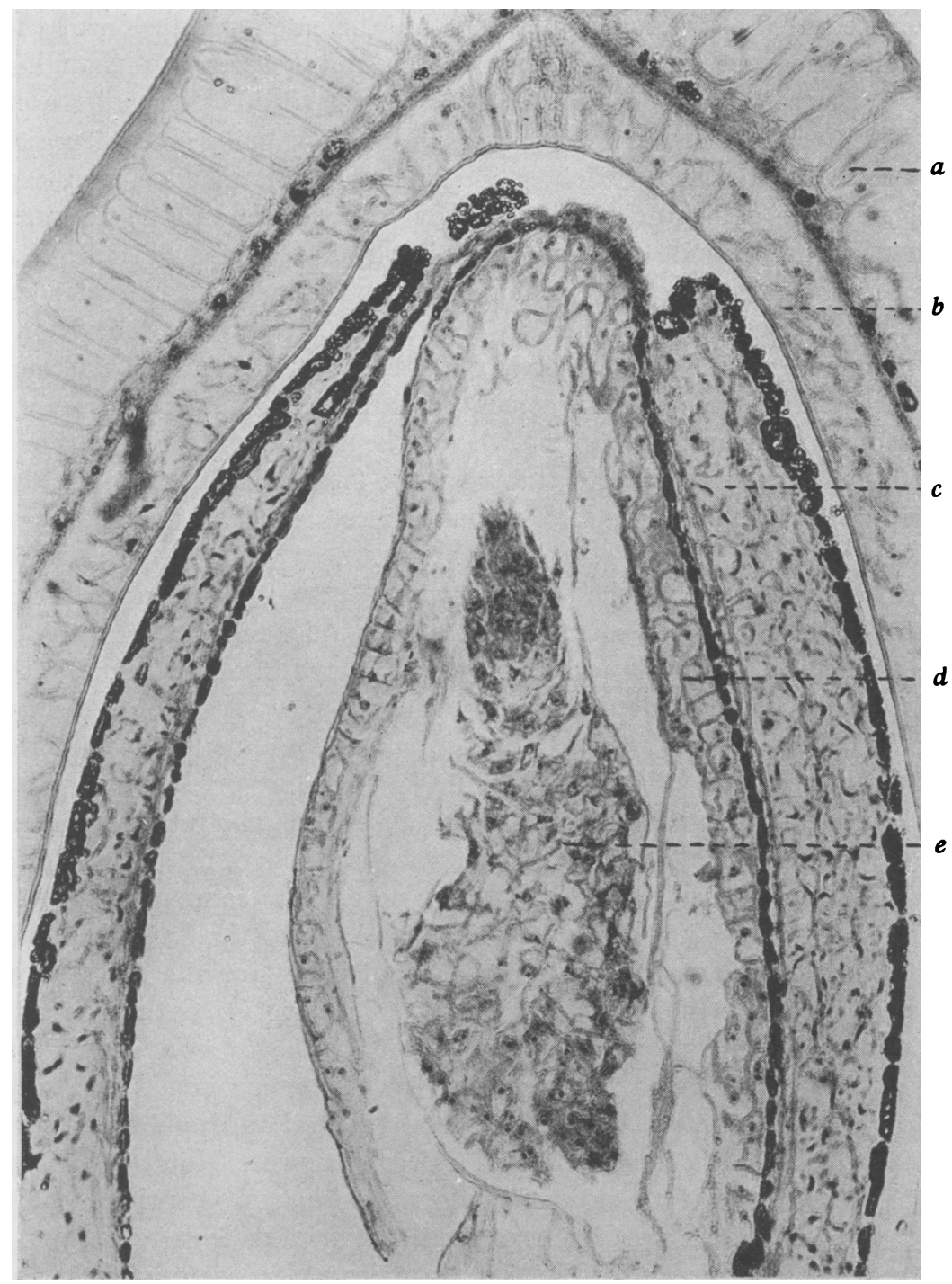

Fig. 7.-Immature ovary or achene of Mission fig flower, breba crop. a, Enlarged epidermal cells; $b$, inner cells of ovary wall becoming selerified; $c$, remains of inner and outer integuments with prominently staining layers; $d$, remains of nucellus; $e$, parthenogenetic endosperm. (X 207.) 
The nuclei and nucleoli are in general very similar in size and shape to those of the normal endosperm. Nuclear fusions were found in my preparations, but the absence of striking irregularities in form of nuclei and in aberrant mitotic figures indicate that they are not of common occurrence.

Cell formation seems to take place in the same manner as in the normal endosperm, but not enough stages were found to determine this with certainty.

As already noted (p. 453), oviposition by the blastophaga so injures the stylar canal that there cannot be a growth of pollen tubes to the ovule. However, such flowers regularly develop endosperm, a tissue which furnishes the main subsistence of the blastophaga larva. The obvious inference that this endosperm is parthenogenetie is confirmed by the determination of chromosome number as shown later.

The development of this type of endosperm has been studied by Longo (1906, 1909) and by Leclerc du Sablon (1907, 1908b). Both investigators state that development of this parthenogenetic endosperm is stimulated by deposition of the blastophaga egg in the ovule just as normal endosperm development is stimulated by the union of the sperm nucleus and the polar nuclei. The fact remains, however, that endosperm development sometimes takes place in the ovules of parthenocarpic figs without the stimulus resulting from oviposition by the blastophaga or from the entrance of a sperm nucleus. Such figs show that neither oviposition nor fertilization is essential in inducing development of endosperm. Coulter (1911) has pointed out that endosperm formation is not dependent upon the entrance of a male nucleus nor even upon the fusion of polar nuclei, and that both of these fusions may be regarded as supplementary rather than determinative. In his work on Fritillaria, Sax (1918) found that the development of endosperm was independent of the development of the embryo. He also found about a dozen cases in wheat where the endosperm developed normally with no embryo present.

The rate of division of the endosperm nucleus may be determined from the stage of development of the blastophaga. According to Grandi (1929) the egg stage of the blastophaga lasts 4 or 5 days. Several of my preparations show that two or three successive divisions of the endosperm nucleus took place while the blastophaga was still in the egg stage. In these flowers, therefore, development of the parthenogenetic endosperm must have followed closely after oviposition. Most flowers, however, do not have a development of the endosperm nucleus until the blastophaga has reached the early larval stage. Even then nuclear divisions proceed rather slowly. 
During the early period of development of parthenogenetic endosperm in the fig ovule, the synergids and antipodals disintegrate. The egg cell may or may not persist. Some egg cells show a slight increase in size, but none show any indication of mitosis of the egg nucleus.

In my preparations the first few divisions of the endosperm nucleus result in nuclei very similar in size and shape to those of normal endosperm. The peripheral region of the parthenogenetic endosperm has a denser cytoplasm than that of the normal endosperm and the outlines of the nuclei are not so clearly defined. The individual nuclei are spherical, ellipsoidal, pyriform, or elongated in shape.
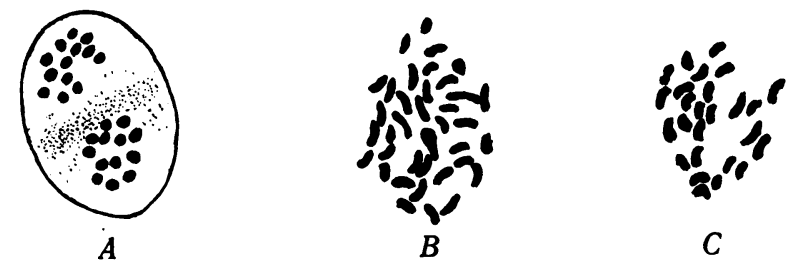

Fig. 8. $A$, Two haploid sets of chromosomes from metaphase plates of homotypic division in the pollen mother cell. ( $X$ 2,600.)

$B$, A metaphase plate of mitosis of a normal endosperm nucleus with 37 of the $3 \mathrm{n}$ complement of chromosomes. ( $X 2,600$.)

$C$, A metaphase plate of mitosis of a parthenogenetic endosperm nucleus with the $2 \mathrm{n}$ complement of chromosomes. (X 2,600.)

Mitoses of nuclei in the free-nucleate stage of the parthenogenetic endosperm have not been found by previous investigators, but mitotic figures in all stages have been found in abundance during the course of the present investigation. Divisions of the free nuclei are not simultaneous, resting nuclei and mitotic figures being found side by side. Here again exact chromosome counts are difficult to make in metaphase plates since the chromosomes are not spread out in a single plane as they are in somatic divisions. Several counts, however, showed clearly that in the free-nucleate stage the chromosome complement is 2 n (fig. $8 C$ ).

Cell formation, according to Leclere du Sablon (1908 $b$ ) starts among the exterior nuclei but does not continue throughout the mass of parthenogenetic endosperm, a zone of free nuclei always being distinguishable toward the center. He does not explain the process by which cells are formed.

There are two general methods in angiosperms by which a multinucleate endosperm becomes a cellular tissue. Cell formation by means of cell plates was described by Strasburger (1880), and his illustration has become widely known by its publication in various 
editions of the "Bonn" textbook (Strasburger, 1895). The cell plates are formed on parallel groups of kinoplasmic threads connecting the free nuclei. Such threads, while similar to, are not identical with the spindle fibers found in mitotic figures; they are special fibers concerned solely with cytokinesis. The cell plates of these fibers divide in the same manner as the cell plates of mitotic spindles and cell walls are then secreted between the membranes separating the naked protoplasts.

Cell formation may also be brought about by a progressive cleavage similar to that found in certain multinucleate fungi and algae (Harper, 1899, 1900; Timberlake, 1902). Frye's (1902) studies in certain Asclepiadaceae show that the multinucleate endosperm becomes cellular by progressive cleavage.

My preparations show that cell formation in the parthenogenetic endosperm of the caprifig is brought about by a more or less simultaneous process of cytoplasmic furrowing as in the second method mentioned above. This begins with the appearance of lighter-colored zones towards the exterior of the dense cytoplasm. There are no indentations at the periphery suggesting the inception of cleavage furrows in the plasma membrane. The lighter-colored zones in the cytoplasm broaden and there appears in the middle of each a distinct furrow (fig. $9 \mathrm{~A}$ ). These furrows are very irregularly arranged with respect to one another. They gradually separate the cytoplasm into irregular blocks containing one or more nuclei. The furrows eventually extend to the surface of the multinucleate endosperm but the outer cells formed by furrowing are as irregular in size and shape as those toward the center. Nuclear divisions and furrowing continue until the central cavity is almost or completely filled with angular protoplasts. The blastophaga larva generally lies in a concavity (fig. $9 \mathrm{~B}$ ) of this cellular endosperm but is occasionally completely surrounded by endosperm tissue.

The process of cell formation just described is analogous to the process of spore formation in certain fungi and algae. According to Swingle (1903), spore formation in Phycomyces nitens is brought about by the formation of angular vacuoles which by branching, curving, and intersecting, eventually form multinucleate bits of protoplasm. Czempyrek (1930) finds that swarm-spore formation in the multinucleate cells of Cladophora is brought about by vacuolation of the cytoplasm.

As already stated, nuclear fusions are found both in the normal and in the parthenogenetic endosperm of long-styled fig flowers, but are more frequently found among the endosperm nuclei of short-styled 


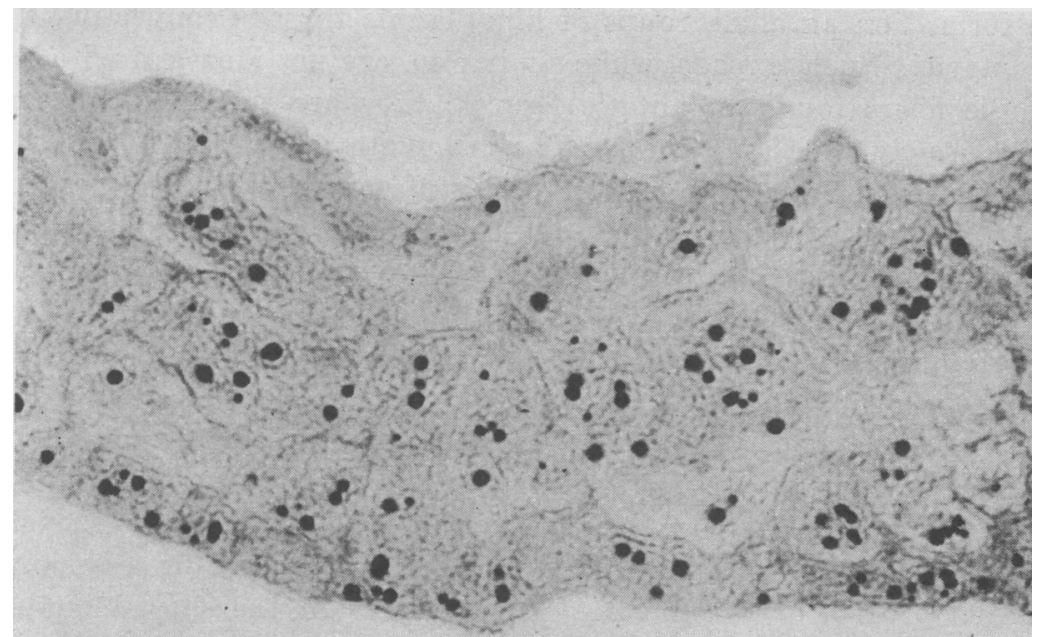

$A$

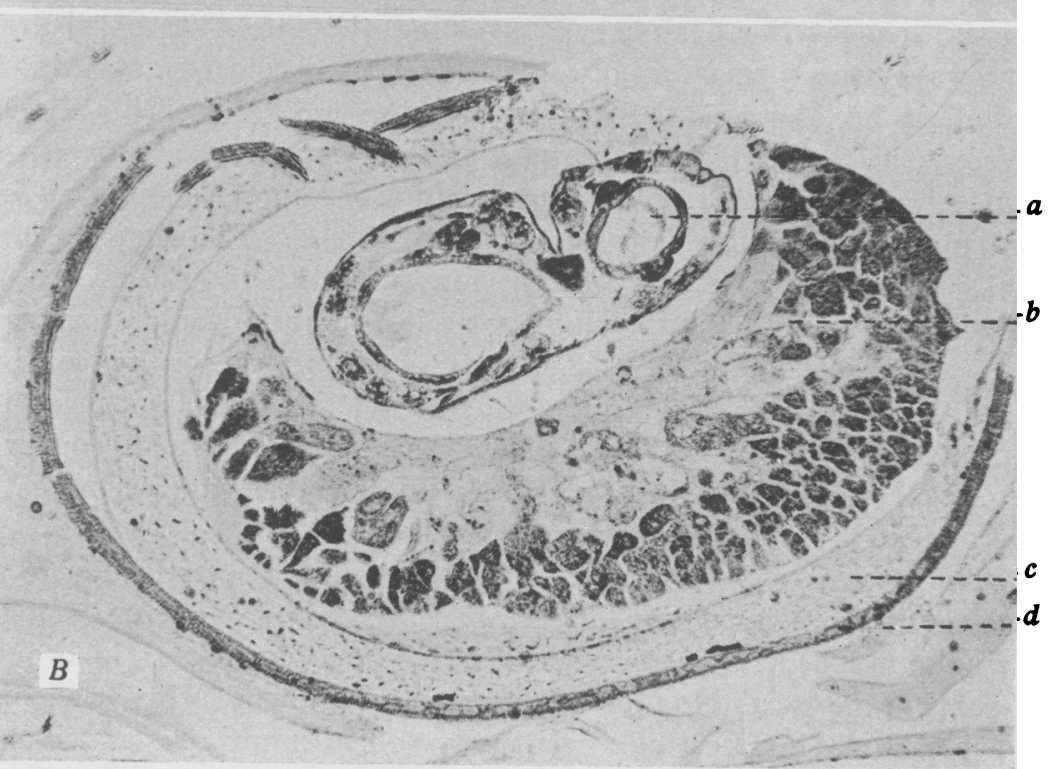

Fig. 9.- $A$, Distinct furrows separating the eytoplasm into irregular blocks containing one or more nuclei, the larger ones polyploid. ( $X$ 450.)

$B, a$, Blastophaga larva lying in a concavity of the cellular endosperm $(b) ; c$, remains of the nucellus; $d$, the partly sclerified ovary wall. ( $\mathrm{X} 68$. 
flowers. These fusions may occur during the free-nucleate stage but are more abundant after the formation of the multinucleate protoplasts. In fact, whenever two or more adjoining nuclei come into close contact, the individual membranes may disappear and the chromatin of the fusing nuclei become indistinguishable.

Nuclear fusion in multicellular endosperm was reported by Strasburger in 1880 for several species of plants, notably Corydalis cava. Tischler later (1900) examined other material of Corydalis and found that the two or more nuclei of a multinucleate cell often fuse, the subsequent divisions being irregular and the chromosome numbers exceedingly variable. The cases of nuclear fusion in endosperm cells have been listed by Tischler $(1922$, p. 507). In all of these, the resultant nuclei are extremely variable in size and shape.

Dixon (1895) decided that some of the polyploid nuclei in the endosperm of Fritillaria imperialis L. divide amitotically, the giant nucleus first assuming the shape of an hour-glass and then breaking into fairly equal portions. A decade later Saame (1906), studying the same species, interpreted such hour-glass-shaped nuclei as fusion stages. Schürhoff (1915) gives an excellent account of amitosis in the resting endosperm nuclei of Ranunculus acer. Schnarf (1929, p. 329) lists a number of plants in which there is amitosis during later stages of endosperm development, but he does not record whether these nuclei have the typical $3 \mathrm{n}$ complement of chromosomes or are polyploid. Longo (1909) found no mitoses in the nuclei of fig endosperm and so inferred that division was by fragmentation.

Polyploid endosperm nuclei have been shown to divide mitotically also. Soltwedel (1882) found both regular and irregular mitotic figures in several species of angiosperms with polyploid endosperm nuclei and thought further fusion took place during mitoses of neighboring nuclei. Both normal and abnormal mitotic figures as well as cases of amitosis, were observed by Dixon (1895) in polyploid nuclei of Fritillaria. Tripolar and quadripolar spindle figures were frequently found to form three or four daughter nuclei. Leclere du Sablon (1908b) states that the mitotic figures in the parthenogenetic endosperm of the fig have an unusually large number of spindle fibers but the chromosomes are not clearly defined.

Some of the material obtained in this investigation, especially that of two forms of Ficus palmata Forsk., is unusually favorable for the study of mitotic figures in the polyploid nuclei of cellular endosperm. Metaphase plates or telophases in the division figures (fig. $10 \mathrm{~A}$ ) of free nuclei are about 7.5 microns in diameter and have the 2n complement of chromosomes. Large metaphase plates (fig. $10 \mathrm{~B}$ ), 
11 microns in diameter, are found during mitoses of polyploid nuclei. These indicate a chromosome complement several times n, although the exact number could not be determined. Conversely, there were very small mitotic figures having metaphase plates much smaller than those of diploid nuclei.

Dixon (1895) found that in multipolar mitotic figures of endosperm nuclei one of the poles appeared to have less attraction for chromosomes than the others, the daughter nuclei being unequal in size. He also found cases in which a few chromosomes with spindle fibers became detached from the metaphase plate. In my preparations the polyploid nuclei of fig endosperm frequently show, during mitoses, an irregular migration of chromosomes toward the poles. Small groups of chromosomes may become detached from the larger group (fig. $10 \mathrm{C}$ ) and form part of the fused nucleus; or they may become separate nuclei that undergo further mitoses.

Abnormal and strikingly irregular spindle figures are characteristic of the parthenogenetic fig endosperm after it has become cellular. The abnormal figures vary considerably in the shape and arrangement of their spindles. Many of the spindle figures are very broad and have a width of 50-55 microns (fig. $10 \mathrm{C}$ ). Some of the transversely elongated figures are typical except for their unusual breadth. Others are more or less curved into very unusual and striking shapes. Some elongated figures have a homogeneous set of spindle fibers (fig. $10 C$ ) while others appear to be formed of individual sets of spindle fibers (fig. $10 \mathrm{D}$ ) lying side by side. The daughter nuclei resulting from abnormal spindle figures are of various shapes and sizes (fig. $10 G$ ). Some are considerably elongated and often amoeboid (fig. $10 \mathrm{H}$ ) in appearance, similar to the nucleus figured by Soltwedel (1882) in the endosperm of Leucojum aestivum $\mathrm{L}$.

Previous accounts of abnormal spindle figures in endosperm nuclei fail to explain satisfactorily the origin of such abnormalities. Two explanations suggest themselves as a result of this study of fig endosperm : (1) the abnormal mitotic figures may be the result of the dense crowding of the nuclei in the multinucleate cells formed by furrowing; (2) they may be due to the polyploid nature of the nuclei. Evidence in support of the first hypothesis is to be seen in the close proximity of the dividing nuclei. Some of these division figures lie side by side with their respective spindle fibers parallel (fig. $10 \mathrm{D}$ ). Others lie almost in the same plane but with the spindles end to end (fig. $10 E$ ). In still other cases the figures are contiguous but diverge at various angles (fig. $10 \mathrm{~F}$ ) from one another. The daughter chromosomes migrating to the poles of these spindles may become more or less 

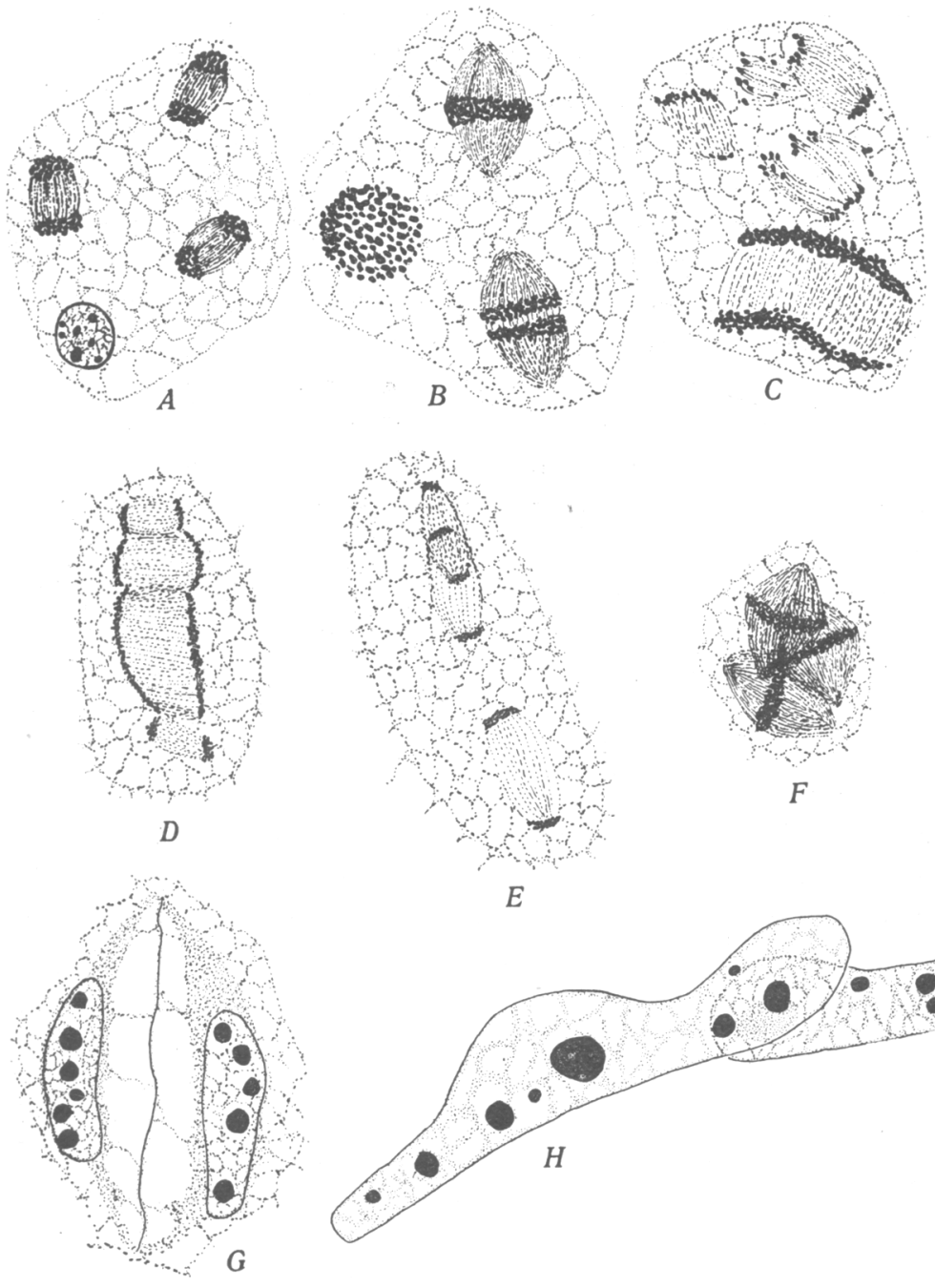

E

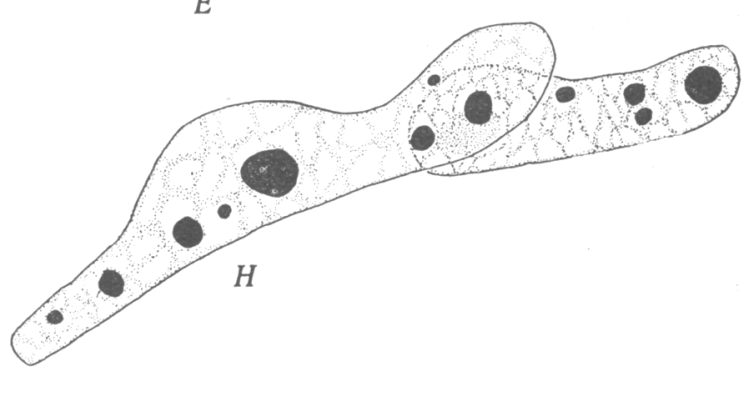

Fig. 10. $A$, Mitotic figures with $2 \mathrm{n}$ chromosomes and a resting nucleus characteristic of the early free-nucleate stage of parthenogenetic endosperm. (X 1,140.)

$B$, Mitotic figures and a metaphase plate of polyploid nuclei indicating a chromosome complement several times $n$. (X 1,140.)

$C$, A broad homogeneous spindle figure of a polyploid nucleus, and spindle figures with groups of chromosomes more or less detached. ( $X$ 1,140.)

$D$, An elongated spindle figure made up of individual sets of spindle fibers. ( $X$ 1,065.)

$E$; Spindle figures lying in almost the same plane with spindles end to end. (X 1,140.)

$F$, Three spindle figures more or less intermingled. (X 1,140.)

$G$, Elongated daughter nuclei resulting from mitosis of a polyploid nucleus. ( $X$ 1,140.)

$H$, An elongated polyploid nucleus amoeboid in appearance. (X 1,065.) 
intermingled with one another during the early telophases, with a resultant formation of polyploid or aneuploid nuclei instead of the normal daughter nuclei. Subsequent fusions of mitotic figures bring about still greater abnormalties, the most abnormal figures being found during the later stages of endosperm development.

If the above explanation is correct, more frequent reports of abnormalties in spindle figures of endosperm nuclei would be expected, especially in species where free nuclei and their mitotic figures lie close together. In the gymnosperms, neither nuclear fusions nor irregular mitotic figures ordinarily result from crowding of free nuclei in the macrogametophyte. Reference is made above to two cases of abnormal figures in the endosperm nuclei of angiosperms, but the literature of endosperm development records very few such abnormalities.

The other hypothesis for abnormal spindle figures takes into account the possibility that the nuclei which make up a polyploid endosperm nucleus more or less retain their individuality during several successive mitoses. Fusion of resting nuclei either in the freenucleate or in the cellular endosperm does not necessarily mean an immediate mingling of chromatin. Nothnagel (1918) has shown that in the triple fusion of a sperm nucleus and the polar nuclei to form the primary endosperm nucleus of Lilium martagon L., a complete fusion or intermingling of chromatin did not immediately occur, as in some cases three groups of spiremes are plainly evident at the time the fusion nucleus first divides.

The nuclear membranes of the polyploid nuclei found in the fig endosperm are not distinct, often making it difficult to determine whether nucleoli in groups are enclosed within a common membrane or are parts of individual nuclei lying in different planes. The location and arrangement of the nucleoli in elongated and amoeboid-like nuclei indicate, however, that their individuality has been maintained during mitosis. As already stated, some of the spindle figures are very definitely composed of distinct sets of spindle fibers, a fact which indicates that the mitotic figures of individual nuclei combine to make up a composite figure.

The study of these abnormal figures in fig endosperm leads me to favor the hypothesis that explains irregularity of division as due to the polyploid nature of the nuclei. It is interesting to note that Johnson (1914, fig. 106) shows a similar irregularity of division for the polyploid primary endosperm nuclei of Peperomia hispidula A. Dietr. that has $14 \mathrm{n}$ chromosomes. Further study of other material 
will be necessary to establish as a certainty the assumption that nuclei more or less maintain their identity in the formation of a polyploid endosperm nucleus.

Mitoses of polyploid nuclei are, in the later stages of endosperm development, generally accompanied by the formation of very definite cell plates (fig. $10 G$ ) on the spindle fibers. Although there is no question of the formation of cell plates, it is not at all certain that their presence results in cytokinesis. These cell plates may be a transitory type similar to those found in the pollen mother cells of Larix (Devisé, 1922).

There is a tendency for the cells in the later stages of endosperm development to become uninucleate. At this stage most of the parthenogenetic endosperm cells, but especially those at the periphery, contain numerous granules similar to but smaller (fig. $9 \mathrm{~B}$ ) than those found in the cells of normal endosperm. The endosperm of short-styled gall flowers is transitory and is entirely consumed by the blastophaga larva at about this stage of its development.

Normal endosperm and parthenogenetic endosperm differ in the following particulars: In normal endosperm, nuclear fusions are not common and mitoses are generally regular; the chromosome complement is usually $3 \mathrm{n}$; cell formation is brought about by cleavage; the peripheral cells are cambium-like in appearance; most cells are uninucleate and their walls are of cellulose. The parthenogenetic endosperm of long-styled flowers has diploid nuclei; cell formation, however, appears to be similar to that of normal endosperm. In the parthenogenetic endosperm of short-styled flowers, cell formation occurs by a process of simultaneous furrowing; the cells are commonly multinucleate, their outlines usually being indistinct and poorly defined; both peripheral and central cells are irregular in size and shape; nuclear fusions commonly occur, the polyploid nuclei being of various shapes and sizes; mitoses of adjoining nuclei frequently form mitotic figures very abnormal in appearance; the chromosome complement is irregular, varying from $n$ to several times $n$. 


\section{EMBRYOGENY}

The development of the fig embryo begins with an elongation of the zygote and a vacuolation at the micropylar end. The zygote nucleus contains a single nucleolus, although daughter nuclei are often multinucleolate.

The first transverse division of the zygote results in the formation of an embryo with a basal and an apical cell. There is then a transverse division of both cells to form a linear four-celled embryo. Usually the division of the basal cell is fully completed before there is any indication of division in the apical cell.

The basal cell or cells develop into a short suspensor, which is transitory and not more than three cells in length. Material showing subsequent stages in the development of the embryo was insufficient to work out the embryogeny in detail. However, it appears to follow the same general type of development as that described by Souges (1921) for Urtica pilulifera L. The young embryo of the fig is at first spherical and remains so until successive cell divisions have formed a massive embryo of several hundred cells. It then becomes flattened at the apex, after which the two cotyledons differentiate in the usual way with the epicotyl between. The mature embryo is curved so that the hypocotyl and the cotyledons lie side by side (fig. 6).

\section{ACKNOWLEDGMENTS}

The work on which this paper is based has been done under the supervision of Dr. Gilbert Morgan Smith, Department of Botany, Stanford University, and to him the writer wishes to express sincere appreciation for helpful suggestions and careful perusal of manuscript.

Acknowledgment and thanks are also extended to Dr. H. A. Borthwick, Davis, to Dr. F. F. Halma, Riverside, and to Mr. W. A. Beall, Fresno, for assistance in the collection of materials at the proper season. 


\section{LITERATLRE CITED}

BoRTHWICK, H. A.

1931. Development of the macrogametophyte and embryo of Daucus carota. Bot. Gaz. 92:23-44. 32 figs.

Condit, I. J.

1922. Caprifigs and caprification. California Agr. Exp. Sta. Bul. 319:341377. 23 figs. (Out of print.)

1926. Fruit-bud and flower development in Ficus oarica. Amer. Soc. Hort. Sci. Proc. 23:259-263.

1928. Cytological and morphological studies in the genus Ficus. I. Chromosome number and morphology in seven species. Univ.

Cook, O. F.

California Pubs. Bot. 11:233-244. pl. \%.

1922. Figs with misplaced scales. Jour. Heredity 13:122, 123. figs. 16, 17.

CotTe, J., and A. ReYNiER.

1923. La dioecie du figuier et Blastophaga psenes L. Compt. Rend. Soc. Biol. 88:500-502.

Coulter, J. M.

1911. The endosperm of angiosperms. Bot. Gaz. 52:380-385.

Czemptrek, $\mathrm{H}$.

1930. Beitrag zur Kenntnis der Schwärmerbildung bei der Gattung Clado-

Devisé, $\mathbf{R}$. phora. Arehiv. für Protist. 72:433, 452. 10 figs.

1922. La figure achromatique et la plaque cellulaire. La Cellule 32:249307. pls. 1-4.

Dixon, H. H.

1895. Note on the nuclei of the endosperm of Fritillaria imperialis. Royal Irish Acad. Proc. 3rd ser. 3:721-726. pl. 24.

EIsen, G.

1896. Biological studies of figs, caprifigs, and caprification. California Acad. Sci. Proc. 2nd ser. 5:897-1002.

FrYe, T. C.

1902. A morphological study of certain Asclepiadaceae. Bot. Gaz. 34:389413. pls. 13-1.5.

GOODSPEED, T. H.

1915. Plarthenogenesis, parthenocarpy, and phenospermy in Nicotiana. Univ. California Pubs. Bot. 5:249-272. pl. 35 .

GrANDI, G.

1929. Studio morfologico e biologico della Blastophaga psenes. Bol. Lab.

Ent. R. Ist. Super. Agr. Bologna 2:1-147. pl 1. text figs. 1-4\%.

HARPER, R. A.

1899. Cell division in sporangia and asci. Ann. Bot. 13:467-525. pls. 24-26. 1900. Cell and nuclear division th Fuligo varians. Bot. Gaz. 30:217-251. pl. 14. 
Johnson, D. S.

1914. Studies of the development of the Piperaceae, II. Amer. Jour. Bot. 1:357-397. text figs. 113-121. pls. 21-93.

LeClerC DU Sablon, M.

1907. Sur la symbiose du figuier et du blastophage. Compt. Rend. Acad. Sci. [Paris] 144:146-148.

1908a. Observations sur les diverses formes du figuier. Rev. Gen. Bot. 20:129-150;207-216. 15 figs.

1908b. Structure et developpement de l'albumen du caprifiguier. Rev. Gen. Bot. 20:14-24. text figs. 1-6. pl. 6 .

LoNGo, B.

1906. Ricerche sul fico e sul caprifico. R. Accad. Lincei Atti. Rend., ser. 5 $15: 373-377$.

1909. Osservazioni e ricerche sul Ficus carica. Annali di Bot. 7:235-256. 3 figs.

1911a. Sul Ficus carica. Annali di Bot. 9:415-432.

1911b. Su la pretesa esistenza del micropilo nel F'icus carica. Annali di Bot. 9:197, 198. 2 figs.

1912a. Sur le Fious carica en Italie. Compt. Rend. Acad. Sci. [Paris] 155:433-435.

1912b. Ancora sul Ficus carica. Annali di Bot. 10:147-158.

MOELLER, J.

1886. Mikroskopie der Nahrungs und Genussmittel aus dem Pflanzenreiche. $i v+394$ p. 308 figs. J. Springer, Berlin.

Noth Nagel, M.

1918. Fecundation and formation of the primary endosperm nucleus in Penzig, 0. certain Liliaceae. Bot. Gaz. 66:143-161. pl. 3-5.

1894. Pflanzen-Teratologie. 2:1-594. A. Ciminago, Genoa.

Ravasint, $R$.

1911. Die Feigenbäume Italiens und ihre Beziehungen zu einander. $174 p$. 61 figs. M. Drechsel, Bern.

1912a. Sul Ficus carica- risposta al Prof. B. Longo. Archiv. Farm. e Sci. Affini 1:14-31.

1912b. Ancora sul Ficus carica. Arehiv. Farm. e Sei. Affini 1:85-116.

RIXFORD, G. P.

1918. Smyrna fig culture. U. S. Dept. Agr. Bul. 732:1-43. 19 figs.

SAAME, 0 .

1906. Über Kernverschmelzung bei der karyokinetischen Kernteilung im protoplasmatischen Wandbelag des Embryosacks von Fritillaria SAx, K. imperialis. Berichte Deutsch. Bot. Gesell. 24:300-303. Taf. 14.

1918. The behavior of the chromosomes in fertilization. Genetics 3:309-327. pls. 1, 2.

SCHNARF, K.

1929. Embryologie der Angiospermen. Linsbauer's Handbuch der Pflanzenanatomie 10:1-689. 66 figs. G. Borntraeger, Berlin. 
SchürHoFf, P. N.

1915. Amitosen von Riesenkern im Endosperm von Ranunculus acer. Jahr. Wiss. Bot. 55:499-519. Taf. 3, 4.

Solms-Laubach, H. G.

1882. Die Herkunft, Domestication und Verbreitung des gewöhnlichen Feigenbaums. Abh. Konig. Gesell. Wiss. 28:1-106.

SOLTWEDEL, F.

1882. Freie Zellbildung im Embryosack der Angiospermen. Jenaische Zeit. Naturwiss. 15:341-380. Taf. 18.

SOUEGES, $\mathbf{R}$.

1921. Developpment de l'embryon ches l'Urtica pilulifera L. Bul. Soc. Bot. France 68:172-188. 49 figs.

STRASBURGer, E.

1880. Zellbildung und Zelltheilung. 3rd ed. 392 p. 14 pls. G. Fischer, Jena.

1895. Lehrbuch der Botanik. 556 p. 594 figs. G. Fischer, Jena.

SWINGLE, D. B.

1903. Formation of the spores in the sporangia of Rhizopus nigricans and of Phyoomyces nitens. U. S. Dept. Agr. Bur. Pl. Ind. Bul. 37:1-40. pls. 1-6.

Timberlake, H. G.

1902. Development and structure of the swarm spores of Hydrodictyon. Tischler, G. Wisconsin Acad. Sei. Arts, Letters Trans. 13:486-522. pls. 29, 30.

1900. Untersuchungen über die Entwicklung des Endosperms und der Samenschale von Corydalis cava. Naturhist. Med. Ver. Heidelberg 6:351-380. Taf. 8, 9 .

1912. Über die Entwicklung der Samenanlagen in parthenokarpen Angiospermen-Fruchten. Jahr. Wiss. Bot. 52:12-30. text figs. 1-5. Taf. I, figs. 1-14.

1922. Allgemeine Pflanzenkaryologie. Linsbauer's Handbuch Pflanzenanatomie 2:1-899. 406 figs. G. Borntraeger, Berlin.

Traub, H. P., and G. S. Fraps.

1928. Ripening and composition of the Texas Magnolia fig. Amer. Soc. Hort. Sei. Proc. 25:306-310. \& figs.

Treub, M.

1902. L'organe femelle et l'embryogenese dans le Ficus hirta Vahl. Ann. Jard. Bot. Buitenzorg 18:124-157. pls. 16-25.

Winton, A. L.

1916. The microscopy of vegetable foods. 2nd ed. $x i v+701$ p. 589 figs.

John Wiley and Sons, New York. 